\title{
JAVAANSCH GRONDENRECHT IN HET LICHT VAN LOMBOKSCHE TOESTANDEN.
}

\author{
DOOR \\ P. DE ROO DE LA FAILLE.
}

I.

-Behoudens opvolging van de tweede en derde bepaling der wet van 9 April 1870 [Ind. St. 1870 No. 55], bekend als de Agrarische Wet - verordent artikel 1 van het Agrarisch Besluit in Ind. St. $1870 \mathrm{~N}^{\circ}$. 118 - blijft het beginsel gehandhaafd, dat alle grond, waarop niet door anderen recht van eigendom wordt bewezen, domein van den Staat is.s Deze domeinverklaring, luidt de toelichting, constateert geen feit, doch handhaaft slechts een aangenomen beginsel; zij bevat geen voor tegenbewijs niet vatbare uitspraak; kent evenmin aan den Staat het eigendomsrecht toe met verkrachting van bestaande rechten van anderen, maar legt alleen den bewijslast op dengene, die eigenaar van den grond beweert te zijn. Hoe de ingezetenen hun eigendomsrecht moeten bewijzen, zegt het artikel niet, luidt het verder. De gewone bewijsmiddelen gelden dus, en nergens wordt gezegd, dat alleen geschreven titels als bewijs kunnen gelden. Gevorderd worden wel bewijzen, maar volstrekt niet eigendomsakten.

Aldus de leer; hoe zijn nu de feiten? Het feit is, dat op Java alle grond, behalve die welke in Europeeschen burgerrechtelijken eigendom wordt bezeten, domein is van den Lande, en behoort, v.z.v. de woeste gronden betreft, tot het vrij, en wat de overige velden aangaat, tot het onvrij landsdomein, en zulks om het even of de Inlandsche bouwgronden communaal, zooals in Midden-Java, dan wel erfelijk individueel, zooals in West- en Oost-Java, worden bezeten. De Javaansche erfelijk individueele bezitter is in zijn handelingsbevoegdheid ten opzichte van zijn grond beperkt wat aangaat zijn transacties met niet-Inlanders, bepaaldelijk is 
rechtstreeksche vervreemding uitgesloten, maar overigens kan hij daarover vrijelijk beschikken, en toch is ook die grond domein, welke Europeanen niet in eigendom kunnen verkrijgen, tenzij door tusschenkomst van de Regeering, die stipt het beginsel handhaaft dat de Inlander zijn grond niet aan den Europeaan verkoopt, maar zijn bezit te diens behoeve ontruimt (zij het tegen ontvangst van een geldsom), waarna het de Regeering is, welke, indien er geen wettelijk bezwaar bestaat, den eigendomstitel verleent.

Zoekt men ten deze licht in het bekende Eindresumé naar de rechten van den Inlander op den grond op Java, dat in drie lijvige deelen de resultaten bevat van het in 1867 te dien aanzien ingestelde onderzoek, dan gevoelt men zich bij die studie als het ware "verplaatst in een doolhof", waarin "niet meer te onderscheiden is, wat recht of usurpatie, gebruik of pretentie is , en begint men te begrijpen, waarom de Regeering-Wetgeefster bij de vaststelling van regelen omtrent de ontginning van grond nu eens haar toevlucht heeft genomen tot een ontwijkende formule, dan weer zich heeft onthouden om de rechtsgevolgen eener ontginning te regelen, en zelfs zoo voorzichtig zich heeft uitgedrukt, dat niet $\mathrm{Zij}$ het is, die aan de bevolking het recht schenkt om woesten grond te ontginnen, wijl dat recht als bestaande wordt aangenomen; zoomede, dat ook al weêr niet $Z_{i j}$ op den ontgonnen grond een recht van erfelijk individueel gebruik verleent ${ }^{\mathbf{1}}$ ), maar dat dit recht een uitvloeisel wordt geacht van de adat.

Deze houding is een uitvloeisel van des wetgevers angstvallige zorg om geen partij te kiezen in den strijd over het domeinrecht, welke in den tijd van de Cultuurwet en nog lang daarna levendig werd gestreden in en buiten het Parlement: aan de eene zijde het historische begrip, nú nog levend in de Javaansche Vorstenlanden [ofschoon thans ook daar ernstig aan het verzwakken] dat de grond toebehoort aan den Vorst, die de beschikking daarover aan zich houdt en alleen het genot, het gebruik van den grond verleent, onder zoodanige voorwaarden als van ouds gebruikelijk is; aan den anderen kant de zienswijze van diegenen, welke met Wilken ${ }^{2}$ ) van meening waren: alle

1) Toelichting der Regelen omtrent de ontginning van grond door Inlanders op Java en Madoera, Batavia 1898, blz. 4, 23 en 49.

2) Wilken, Handleiding uitgeg. door C. M. Pleijte blz. 430, 440. 
gronden zijn het eigendom van een of ander district en het district is als staatkundige eenheid souverein over den grond, waarop de leden van het district, onder zekere voorwaarden, een recht van vruchtgebruik kunnen verkrijgen.

Duidelijk is mij de quaestie eerst geworden op Lombok bij het agrarisch onderzoek van $1895-1897^{1}$ ), dat aldaar noodig was geworden na den val van het Balineesch gezag ter beslechting van den strijd tusschen de Sasaks en de Balineezen om den grond, een strijd, waarin de Sasaks zich gerechtigd hadden geacht om als bondgenooten van de overwinnende Hollanders alle Balineesch bezit te accapareeren, hun overwonnen meesters en het Ned. Indisch Gouvernement niet meer latend dan zij kwijt wilden zijn. Hierbij toch kwam het rijk van Lombok voor ons te liggen als een onafzienbare oppervlakte domeingrond, waarover de Balineesche Vorst had beschikt, te rade gaande met zijn eigen belangen en die ten opzichte zijner grooten en onderhoorigen, aan de eersten gronden wegschenkende, tot vrij en eigen bezit, aan zijn volk aandeelen in het vorstelijk domein ter bewerking of in gebruik gevend, behoudens dienstplicht, deelbouw of tegen belasting in geld, een en ander v.z.n. met in achtneming van rang en stand der betrokken personen. Was nog kort voor die gebeurtenis in een meesterlijke studie ${ }^{2}$ ) Bali en bepaaldelijk het landschap Boeleleng ons geschilderd als een gebied, van ouds ingenomen door autonome desa-republiekjes, welke, hun rechten krachtig handhavend, in hun vorst wel is waar een "Verheven Mensch » erkenden, wien alle eer toekwam, maar toch vooral in hem zagen den scheidsrechter bij hun herhaalde onderlinge geschillen; - tegenover dit Balineesch Boeleleng, waar de grond geacht werd den goden te behooren, en waar de uitdrukking Sang Amawaboemi (of: - rat) vrij wel een modern begrip was geworden, stond thans in levendige tegenstelling Balineesch Lombok als een machtige alleenheerschappij, waar de vorst, omgeven door trotsche rijksgrooten, en steunende op zijn gewapende getrouwen, over het gansche eiland gebood, beschikkende over grond en water, lijf en goed.

Dit verschil is groot, maar niet onverklaarbaar. De Boelelengsche Radja's toch waren van ouds weinig meer dan aanzienlijke leenmannen, aanvankelijk van den Tjokorda van Mengwi, later van de Karangasemsche Vorsten; stedehouders van een

1) Adatrechtbundel XV blz. 131-297.

2) Tijdschr. B.tav. Gen. dl. 33 (1890) blz. 429, 371/2. 
verren opperheer, die, in het bezit van eigen familiegronden, met plaatselijke middelen over 's Vorsten gebied een landsheerlijk gezag uitoefenden, met onder zich een op eigen volk steunenden, machtigen landadel van poenggawa's, die in hunne desa's een invloedrijke positie innamen, terwijl het bergachtige land en de zelfstandige volksaard hun noopten om binnen billijke grenzen te blijven. In Raffles' tijd konden de twee Radja's van Boeleleng niet meer dan een paar honderd tenah hun eigendom noemen [vermoedelijk, behalve door familie-erfrecht en koop, verworven dor $r$ naasting (tjampoet) of verbeurdverklaring overeenkomstig de landsinstellingen], terwijl de landsinkomsten uit de overige gronden meest opgingen aan belooning voor diensten en bestrijding van uitgaven, welke krachtens de adat op den Vorst rustten. En toen, na den val der Karangasemsche dynastie in 1850, Boeleleng, na een korte poos onder Bangli te hebben gestaan, een Gouvernementslandschap was geworden, werd het bewind gevoerd door een zelf gekozen landsman, den pambekel van Midden-Boeleleng onder gestadig toezicht van het Europeesch Bestuur, terwijl het na 1870 rechtstreeks uitgeoefend Nederlandsch Gezag zeer mild is geweest.

Anders was de loop van zaken op Lombok. In den heel ouden tijd een schatplichtige onderhoorigheid van Java, stond Sélaparang in het eind der XVII eeuw, naar het schijnt, onder een van Soembawa afkomstigen Dato Mrradja, wiens gezag te loor ging (1692) te midden der woelingen zijner landschapshoofden van Oost- en Midden- Lombok. Eén hunner, het hoofd van Pedjanggi, haalde vervolgens Karangasem op Bali naar de Boemi Sasak. Gaarne gaf die landsheer aan Sasak's roepstem gevolg; stak met een flinke krijgsmacht over naar Ampenan, zette zich daar vast, en onderwierp geleidelijk het vlakke land bewesten het wilde woud van Midden-Lombok; damde bij Sasaot en Gebong het rivierwater op, legde sawahs aan, en stichtte op den duur de vier stad-rijkjes Pagæsangan, Pagoetan, Tjakranegara en Mataram. Dan breekt in $1838 \mathrm{de}$ familiestrijd uit tusschen Tjakranegara en Mataram, een bloedige strijd, waarin Pagěsangan en Pagoetan deelen en de Sasaksche hoofden van Batoeklijang en Praja bijstand verleenen. Mataram triumfeert en verklaart al het veroverd land tot buit, den voormaligen bezitters een deel latend, maar het meeste aan zich trekkend. De Sasaksche bondgenooten worden met onderscheiding behandeld maar steeds met waakzaam oog gadegeslagen. 
Eerst rebelleert Praja; in 1855 maakt Kalidjaga aanstalten om tegen Mataram op te staan en wordt weggevaagd. Met krachtige hand heerscht dan de Balineesche Vorst van MataramKarangasem over gansch Sélaparang, rustig zijn tijd afwachtend tegenover de Sasaksche landschapshoofden, die na hun onafhankelijkheid vroeg of laat mede hun bevoorrechte positie gaan inboeten. En van dit overwinnend Balineesch bewind heeft ons gezag in 1894 de erfenis anvaard.

\section{LOMBOK,}

Wat gold nu op Lombok tijdens het bestuur van dien laatsten Balineeschen Vorst met betrekking tot den bodem als recht?

Eenstemmig verklaarden allen, zoowel Balineezen als Sasaks, dat de grond behoort aan den Vorst, alle grond, bebouwd of onbebouwd, en zulks krachtens verovering, hetzij in den lateren, hetzij in den vroegeren tijd. Stad en land, bergen en bosschen, sawahs en tuinen; bronnen en rivieren, - het was alles zijn; hij behield voor zich of schonk daaruit weg naar goedvinden; nu eens reserveerde ${ }^{1}$ ) hij uitgestrekte terreinen veld en bosch voor zijn eigen jachtvermak - een doorn in het oog der om-

1) Een voorbeeld van een dgl. „larangan", d. i. verboden veld geeft de volgende akte uit West-Lombok: Poepoet pakajoenan Ida Anakke Agoeng, Agoeng Gede Ngoerah Karangasem mawangoen larang ring pajar alasan Batoelajar, mangké wawalẽddan larangan né kaoeh noehoet saillak-iloek kongkor Batoelajar ika, tiba ka panaběng, saking panabĕng matagĕl ngĕlodan. tiba ka otak Teloka, saking otak Teloka matagel ngĕlod ngawoehang noehoet saïlakiloek paälasan Batoelajar tiba ka otak Nanggoel, noehoet sailak-iloek Goenoeng Nanggoel, saking Goenoeng Nanggoel matagĕl nĕdoenang běnah kaoeh tiba ka orok Batoe lajar, ngararis atēp ka toekad Batoe lajar, saïka alassé kapoengětang, tĕlassing tan kawasa djawining langlang-dalĕm mawoek kadjeroning alas larangan, jan ana salah toenggal djanma mawoek kadjeroning larangan tan saking paloegrahang Ida Sang Liningga moenggoehingarěp, těka wěnang olih i langlang mangrampas sagagawané, makadi angoeningajang atoer ring Ida Sang Liningga moenggoehingarĕp, mangka mamargi karaossang ingan pakajoenan angraossin; jan langlang tjĕlěd, nora anindihang mangrampas né wĕnang rampas ngawitan atoer né wěnang witan atoer makadi nora gati njamboetang pahajahang ring laràngan, wĕnang $i$ langlang karaossang mawoek ka Boeï, ingan pakajoen Ida Sang Liningga moenggoehing ngarĕp, itjalla sěngkěr. - Malih pagoemijan Batoelajar né kambil antoek Ida Sang liningga moenggoehingarěp, parasida ngadalem ngawit saking tepin alas larangané, kaoeh toekad Batoelajar, noehoet saïlak-iloek tepin toekad Batoelajar.... soerat gĕgĕm ika kawangoenang tigang lĕmbar, kahatoer ngadalěm salambar, kapangandikajang nggamĕl Batoelajar gadoeh salembar, langlang gadoeh salembar, wirasa toenggal, woes malingga tjap drwé. 
wonende Sasaksche landbouwers, dan weer gelastte hij wijde grasvlakten open te stellen voor het weiden van vee ook uit andere desa's dan die, waar die grond gelegen was, of stelde hij bosch ter beschikking om timmerhout te halen; - - kortom hij was in den vollen zin des woords Sang Amawa boemi, met betrekking tot den grond van zijn rijk was gezag en eigendom één.

Ofschoon nu alle grond als zijn domein was te beschouwen, zoo onderscheidde men toch twee categorieën:

A. het eigenlijk, te zijnen dienste bewerkt domein [drwé dalěm ${ }^{1}$ )] en

B. het erfelijk individueel bezit ‘buiten de poeri> [drwé djaba], toebehoorend meest aan voorname families en inzonderheid aan Balineezen, doch ook wel in handen van personen behoorende tot de volksklasse, zelfs van Sasaks.

\section{A. Drwé dalem.}

Alle grond was van den Vorst, voor hem en zijn volk. De op tripangvangst rondzwalkende Orang Badjo, zeevolk uit Mandar enz., mochten op zijn grondgebied zich bevinden en groote kampongs hebben aan het strand onder eigen matowa's, zij woonden er krachtens zijn vergunning, en, ofschoon desgevorderd hem kleine diensten bewijzend, grondbezit hadden zij niet (behalve de matowa eenig patjatoe), slechts in gebruik de plaats hunner vestiging; hoogstens had aan de stille, verre noordkust een enkele hunner tegen wat opgespaard geld eenige katoenveldjes in 'gade, met een lontarbewijs van het plaatselijk hoofd. Een rijke Chineesche handelaar te Ampenan als Si Krtjoe mocht zich door kostelijke geschenken de gunst des Vorsten en tegen klinkende munt den ijdelen titel van Goesti Gedé Bandar verwerven benevens de vergunning om zich een lustverblijf bij de Goeha Raksasa te doen aanleggen, - toen hij kinderloos kwam te overlijden, werd, evenals gold het een Balinees, zoo goed als alle bezit genaast, en als gunst zijn bijvrouw met een neef gelaten in het genot van eenig geld benevens hare sieraden. Said Abdoellah, de invloedrijke Arabische handelaar en vertrouwde van den Vorst, had weliswaar vergunning gekregen op Pèlangan tuinen aan te leggen, maar hij was dan

1) Dalěm (in) en djaba (buiten) ten opzichte van 's Vorsten poeri. Zoo werden ook misdadigers wel aan de poeri vervallen verklaard; vgl. het Palembangsch. Jaranasche mandjing in piagem TBG, 35 blz. 211/4. 
ook al zeer lang in hooge gunst dank zij 's Vorsten Sasaksche gemalin Denda Aminah, die, waar zij kon, de belangen van haar geloof en hare geloofsgenooten bevorderde: toch was nog niet dadelijk geregeld op welke wijze deze Said zijn landje mocht bezitten, en, toen de Sasaksche opstand uitbrak en hij zelf, van verraad overtuigd, werd gekrist, naastte de vorst alles.

Vorst en Rijk waren één, en beider belang werd gediend door de beschikking over het zeer uitgestrekt domein, drwé dalěm. Alleen krachtens dienstpraestatie kon men een aandeel in dien grond hebben; dienstbaren van allerlei aard: krijgslieden, goudsmeden, houtbewerkers, 's vorsten boodschappers en volgelingen, te veel om op te noemen, zij allen werden, zoo mogelijk in land bezoldigd; zoo mogelijk, want er waren nog steeds vorstendienaren, die zich met een toelage in rijst (pakoerenan) moesten vergenoegen, in afwachting tot er wat land zou openvallen. 's Vorsten eigen volk, de Bali Mataram, erlangden in beginsel één těnah, de andere Balineezen van Lombok daarentegen slechts een halven těnah sawah padjegurij ambtsveld, petjatoe; hadden zij meer in bewerking, bijv. aan tuingrond, dan betaalden zij daarover 's vorsten landrente. Padjegviij pétjatoe was ook het dienstplichtig bezit der adellijke Sasaks (perwangsa), die als geweerdragers of lansknechten fungeerden. Zoo o.a. die van de wijk Karang Gebbang in Tjakranegara, trouwe volgelingen van den Vorst, die in den beruchten Nacht van Overval (25 op 26 Aug. 1894) fel op de lastige Hollanders hebben gevuurd. Van ouder tot ouder, sinds de komst der Balineezen op Lombok ${ }^{\mathbf{1}}$ ), hadden deze Sasaks de zijde van den overwinnaar gekozen en waren tot belooning en in verband met hun adellijken rang in 's Vorsten dienst genomen als parěkan, met behoud van hun sawahs en tuinen en ontheven van padjeg en oepeti.

De groote massa der Sasaks was echter dienst- en tevens landrente-plichtig: van hunne sawahs brachten zij jaarlijks domeinpacht in padi (padjeg), van hunne tuinen oepeti in geld op en hadden verder, zoodra de landbouwwerkzaamheden het maar eenigszins gedoogden, voor allerlei doeleinden vorstendiensten

1) Volgens hun traditie was hun aanvankelijke woonplaats Mĕdaïn, aangelegd in het door hen ontgonnen bosch van Djĕrnèng en zijn van daaruit successievelijk Bertais, Njoerlembang, Telagangěmbĕng en Lingsar gesticht, sawahs en tuinen aldaar aangelegd. Zelfs gaven zij nog de grenzen van hun oude desagebied op, doch onder de Balineesche heerschappij was aan hun zelfstandigheîd een einde gekomen. 
te praesteeren; bij honderden kwamen zij op, om de bijv. tien dagen elkander afwisselend ${ }^{1}$ ), zelf in hun onderhoud moetende voorzien. Voor een uitgestrektheid sawah van 800 patjĕrakèn domeingrond, een zgn. těnah, eischte de Vorst één dienstplichtige (pengajah), en, gold als beginsel, dat van die ééne tenah sawah, waarvan de opbrengst in West-Lombok gemiddeld op 400 bossen (tjěkěls) padi gesteld was, den Sasakschen bewerker of kroonboer, de helft toekwam terwijl de wederhelft het aandeel was van den Vorst-domeinbezitter, zoo werd, omdat die kroonboer mede aan diensten was onderworpen, diens aandeel in de opbrengst vergroot tot $\frac{5}{8}$ [nandoe pengajah], maar daarmeê was het ook uit: in gewonen vorstendienst opgeroepen, had de kleine man van huis zijn eigen teerkost (sangoe) mede te brengen, en verder stipt voor zijn aandeel in de padi-leverantie van zijn dienstplichtige groep te zorgen.

1) Deze diensten voor 's Vorsten bouwwerken (w. o. te begrijpen die voor den aanleg van 's Vorsten wegen naar zijne hoofdsteden en lustverblijven) droegen hetzelfde karakter als op Java de Gouvernements-heerendiensten, welke in het tijdvak 1840-1850 bij duizenden zijn gevergd voor 's Lands vestingwerken; zij drukten op het dienstplichtig domein, zoodat deze dus niet verschuldigd waren door de onvrije landlieden op de sawah djaba der Balineesche grooten, welke meesters gelijksoortige diensten van deze hunne sepangan mochten eischen. Toch "leende" de Vorst somwijlen wel van zijne voorname goesti's deze werkkrachten, evenais die op hunne beurt wel van den Vorst vergunning kregen om de diensten der onder hen gestelde dienstplichtigen ten behoeve van toebereidselen tot groote feesten te requireeren. Een limiet was voor deze diensten niet gesteld; in de practijk vorderde de Vorst in het padi-seizoen slechts een deel van hct volk als saradan, bijv. T'o gedeelte, na den oogst echter had massale opkomst plaats (gěbogan). De karija dalem, welke de Balineezen in den vorm van wachtdiensten, toebereiden van spijzen (maēbat) in de poeri enz. verrichtten, herinneren aan de Javaansche pantjëndiensten voor de regenten en inlandsche hoofden in de Gouvernementslanden, d.z. de sikepdiensten uit den ouden lavaanschen en Compagniestijd. Vgl. de Boelelengsche ajahan taroena in T.B.G. $23 \mathrm{blz} .171$.

Op Lombok rustten de diensten voor het onderhoud der groote, door het sawahgebied loopende wegen op de uit het waterwerk bevloeide sawahs, t.w. op de bewerkers daarvan, onverschillig of deze sawahs drwé of djaba waren, en zij werden gevorderd op den grondslag van één man per twee tenah sawab. Zij behoorden met die voor het onderhoud der leidingen, het herstel van den dam, het verplicht deelnemen aan het jaarlijksch offerfeest en het uitkomen daartoe met een kemphaan voor het hanengevecht tot de waterschaps verplichtingen. Dit zijn de ajahan soebak.

Een derde categorie van diensten vormden die voor de desa, welke op West-Lombok, waar voor de desa feitelịk de kampong in de plaats was getreden, beperkt waren tot het onderhond van wegen en het betrekken van wachten in de kampongs of goeboegs, de zgn. ajahan desa. 
Dit dienstplichtig domein (bangkět pengajah) was groepsgewijze in perceelen uitgegeven, elke groep staande onder een eigen buurthoofd (klijang tèmpèk of klijang pengajah), welk buurthoofd direct ondergeschikt was aan een of anderen poenggawa, het hooger hoofd of den rijksgroote, die door den Vorst met het gezag over die groep dienstplichtigen benevens het beheer van het daaraan toegewezen stuk domein was bekleed. De poenggawa had van 's Vorsten schatmeesters, één over het padjegen één over het oepeti-plichtig domein, een lontaropgaaf (pepanggæran ${ }^{1}$ )) ontvangen, waarin het onder zijn hoede gesteld domeinperceel was aangeduid met de opgaaf van het aantal bossen padi of risten kèpèngs dat jaarlijks in 's Vorsten pakhuizen diende te worden ingeleverd; de in Chineesche duiten (kèpèng) berekende ${ }^{2}$ ) oepeti in de schatkamers van den Majoera-hof, de padi van 's Vorsten dienstplichtig domein in loemboengs, waarover het opperste beheer berustte bij den ouden Ida Wajan Alit Méwě, den trouwen Rentmeester (sedahan agoeng) van het padjegplichtig kroondomein. Er was voor 's Vorsten huishouding heel wat noodig ter spijziging der vorstelijke familie, dezer volgelingen en het 850-tal vrouwen, dat de poeri bewaakte. Elken kliwondag werden te Tjakra uit 's Vorsten voorraad een duizendtal bossen tot rijst verstampt en uitgemeten: een vorstenzoon ontving 5 tjatoe's (klapperdop) zuiver witte rijst, een parækan 1 tjatoe grauwe soort enz. Hetgeen niet noodig was voor den Vorst, werd voor zijne rekening onder toezicht van den Rentmeester door tusschenkomst der poenggawa's verkocht.

In de desa reikte de rentmeester (sedahan) van den poenggawa aan diens klijang pengajah, het buurthoofd van de onder hem gestelde dienstplichtigen, een lontaropgaaf (soerat patjahtjah) uit, waarop naamsgewijs het aantal bossen padi werd aangeduid hetwelk na den oogst elk dezer had op te brengen, soms (echter zelden) na eenige afschrijving wegens misgewas. Niet altijd was bij een geslaagd gewas het padi-bedrag voor alle pengajahs even groot, daar veelal de grootte der aandeelen verschillend was. De reden van dit verschil was gewoonlijk niet meer na te gaan, en in principe kwam in de eenmaal aangenomen verdeeling geen verandering. Elke dienstplichtige had

1) Zie Adatrechtb. XV blz. 301 en blz. 230 vlg.

2) De oepĕti bedroeg 2.000 kèpèngs per tjoetak van 800 (domas) patjĕraken tuin (koebon). 
het recht om na zijn dood opgevolgd te worden door zijn oudsten werkbaren zoon, mits deze aannam de op den grond liggende verplichtingen na te komen, en de poenggawa wachtte zich wel om eigenmachtig op dit recht inbreuk te maken. Bij nieuwe ontginning van grond sprak het begrip: één těnah patjěrakan domas per dienstplichtige zich duidelijk uit in des Rentmeesters vergunningsbewijs, maar het spreekt van zelf, dat in de practijk de een wel meer ontgon dan de ander, terwijl het mede niet zeldzaam was, dat een pengajah een broeder of ander familielid in zijn grond liet deelen. Zulks was hem niet verboden, slechts bleef hij voor zijn gansche aandeel in de padjeg en den vorstendienst aansprakelijk. Zoolang hij zijn verplichting nakwam, was den pengajah het genot van zijn veld verzekerd; zoo niet, dan werd het hem door den klijang op last van den poenggawa ontnomen en aan een ander gegund. Verkoop of verpanding was uiteraard uitgesloten. Dit gold natuurlijk evenzeer van andere domeingronden, met name van de z.g.n. petjatoe's, domeinsawahs, welke ter belooning voor bijzondere diensten van padjeg en oepeti ontheven werden; de vruchtgebruiker had het vol genot (boekti) van dien grond, kon dien zelf bewerken of verpachten ${ }^{1}$ ), slechts moest het recht op den grond onverlet blijven. Groot ambtelijk landbezit was er niet. De voorname bahoe danda's of poenggawa's toch hadden immers hun eigen djaba-landerijen, onbelast en vervreemdbaar, en genoten bovendien een aandeel in den verkoop van 's Vorsten padi, welke door hun onderhoorigen als padjeg werd opgebracht, terwijl sommigen nog wel begunstigd werden met eene uitkeering in padi en geld. Maar petjatoe in grond, die als zoodanig onvervreemdbaar, dus als het ware onvrij was, was bestemd voor de lagere categorieë.ì van 's Vorsten dienaren, en dan voor hen, die van de heffe des volks, de massa der pengajahs, waren te onderscheiden; met name de parěkan, de djoeroe-toembak, -bědil enz., welke uit de adellijke Sasaks en 's Vorsten eigen Balineezen werden aangewezen en die als zoodanig ontheven waren van de padjeg en oepeti hunner petjatoe's.

1) Het plantsoen volgde den grond; hetgeen een pachter of bewerker op het veld plantte, bleef daartoe behooren, indien het pachtcontract eindigde of het gebruik ophield; schadevergoeding was niet verschuldigd. Echter plachten op djabagronden wel onderhandsche regelingen (geen ontneming gedurende een aantal jaren bijv.) te worden getroffen. 
Tot deze groep dienen mede te worden gebracht de z.g.n. paoemangronden, padjegvrije domeinsawahs, die het petjatoe vormden van een groep van eenigermate onderscheiden dienstplichtigen, die te talrijk waren om in het aangewezen grondstuk elk zelf een behoorlijk aandeel te bewerken en zich daarom hadden te vergenoegen met eenige bossen padi uit de algemeene opbrengst. Dgl. paoeman's plachten te worden beheerd en verpacht door het buurthoofd, den klijang, terwijl na den oogst de opbrengst gemeenlijk werd bewaard om in voorkomende gevallen de opgeroepen dienstplichtigen van teerkost te voorzien.

Met dienzelfden naam werden aangeduid sawahs of tuinen, waarvan de opbrengst door den Vorst was toegewezen aan zekere instellingen, zonder dat hij het noodig had gevonden om, zooals in andere gevallen wel gebeurde, dien grond aan de instelling te schenken. Kleine tempels, enkele Sasaksche bedehuizen en heilige graven, ook wel belangrijke bevloeiïngswerken hadden van dgl. gronden het genot (boekti).

Nog steeds nam het domein in uitgestrektheid toe. Kwam een huisvader zonder zoons te overlijden, dan verviel krachtens de Balineesche instellingen het overblijvend gezin met het gansche bezit aan den Vorst, die, naar gelang van de omstandigheden, al dan niet dan wel meer of minder van dit recht gebruik maakte. Was de boedel van een Balineeschen voorname zóó bezwaard, dat de erfgenamen dezen niet wilden aanvaarden, de Vorst nam deze verplichtingen en de lijkverbranding op zich, doch naastte dan ook de nalatenschap. Dergelijke bezittingen lágen gewoonlijk in kleine stukken verspreid (ngantjil), en omdat: ze daardoor zich niet leenden tot uitgifte aan dienstplichtige groepen, reserveerde de Vorst deze tanah pengantjil om ze te eenigertijd weg te schenken. Middelerwijl werden dgl. perceeltjes aan den meestbiedende in gebruik gegeven, hetgeen voor sawahs neer kwam op zuiveren halfbouw (nandoewang), uiteraard steeds zonder dienstplicht, opdat de Sasaksche bewerker na aflooj van den oogst geen aanspraak op voortzetting van het genot der sawah zou kunnen doen gelden, hetgeen den Vorst in zijn schenkingsrecht zou hebben belemmerd.

In Midden- en Oost-Lombok, waar nog niet; zooals in de prachtig bebouwde en besproeide sawahvlakte van West-Lombok, alle woeste grond in sawah of klappertuin was herschapen, nam het dienstplichtig domein gestadig toe door ontginning. Herhaal- 
delijk gaf 's Vorsten rentmeester lontar-brieven af, waarbij aan een groep van dienstplichtigen vergund werd om sawahs aan te leggen; elk der daarin met name vermelde personen werd gesteld op één tenah sawah dan wel op 2 tjoetak koebon, terwijl voor het buurthoofd en den geestelijke der nieuwe nederzetting werd gerekend op elk één tenah padjegurij ambtsveld (petjatoe) naast hun individueel aandeel (sakapan) in het dienstplichtig domeinperceel. Tot goedmaking van den ontginningsarbeid werd van dgl. nieuw aangelegde bouwvelden gedurende eenige, meest drie jaren geen domeinpacht of dienst gevorderd; na ommekomst van dien termijn werd het land opgemeten en wel is waar den bewerkers in gebruik gelaten, maar ingelijfd bij het dienstplichtig domein en op den gebruikelijken voet bezwaard met padjeg, oepeti en ajahan drwéné.

Gansch Lombok was als het ware bezaaid met dergelijke perceelen dienstplichtig domein, met, vooral in West-Lombok, daartusschen door talrijke landerijen der Balineesche aanzienlijke geslachten, die voor dezen werden bewerkt door hunne slaven (sepangan). Streng gescheiden bleven deze twee hoofdgroepen, het dienstplichtig domein en het belastingurij privaatbezit, maar de wijze van ingebruikgeving verschilde in het wezen der zaak niet, want voor het lagere volk kwam, uit een oogpunt van lasten, de zaak ongeveer op hetzelfde neder. Padjeg en oeperti waren de namen óók voor de pacht in natura of 'geld der particuliere bezitters; bij de sawahs was halfbouw de gebruikelijke vorm, alleen bij tuinen was geen eenvormige aanslag, terwijl soms bijzonder werk werd gemaakt van de leverantie van bladeren enz. (ron, boesoeng) met het oog op de talrijke godsdienstige feesten en ceremoniën der bezitters. En voorts waren de slaven dienstplichtig in beginsel uitsluitend aan hun eigen heer, de Vorst «leende» ze slechts af en toe, zoodat het verschil tusschen een Sasakschen kroonboer (kaoela drwéné) en een Sasakschen onvrijen dorper (sepangan) op het land van een Balineeschen groote hoofd7.akelijk in den persoon des meesters bestond.

Gelijk bij. herhaling gronden met Sasaksche kaoela's zijn weggeschonken aan aanzienlijken, zoo heeft ook meer dan eens de Vorst sepangans, wier klacht over willekeurige behandeling van de zijde huns meesters (goesti) gegrond werd bevonden, geruild tegen pengajahs. Een noodlottige gebeurtenis was het verlies van de vrijheid, schandelijk was de slavenhandel over 
zee met alle willekeur en meêdoogenloosheid, die daarmee gepaard ging (deze was trouwens op aandrang van onze Regeering verboden), maar de erfelijke dienstbaarheid van den dorper ${ }^{1}$ ), die zijns meesters land in halfbouw of tegen opbrengst van een deel der boomvruchten dan wel van oepetti bewerkte, verschilde in wezen niet, slechts gradueel van den staat van een kaoela; Sasaksche sæ̌pangan tigehan mochten dan ook door schaking overeenkomstig de landsinstellingen (ngrangkat) zich een vrouw verwerven op gelijke wijze als 's Vorsten mohammedaansche dienstplichtigen en dan tegen een prijs (adji) als voor deze categorie, de kaoela of perdjaka, was bepaald.

B. Drwé djaba.

«Buiten, het domein stonden de reeds meer genoemde erfelijk individueele bezittingen (drwé djaba). Aanzienlijke Balineesche geslachten, zooals die van I Goesti Njoman Wanasara en I Goesti Njoman Kaler, beiden te Mataram, telden hun djabalanderijen bij eenige honderden tenahs, en het waren vooral de leden der drie hoogste kasten, de zgn. triwangsa, die in dgl. grondbezit zich verheugden, maar er waren toch ook wel stukjes van één of meer tenah, die toebehoorden aan rijk geworden kleine luiden, wien de aankoop daarvan was toegestaan. Zoodanig grondbezit was, behoudens bij leden van de Vorstelijke familie, oorspronkelijk gedekt door een giftbrief (soerat piťmæss), later veelal door een koopbrief, welke ten blijke van 's Vorsten vergunning den stempel droeg van kaloegraha; want, was het dezen bezitters in beginsel toegestaan ${ }^{2}$ ), hun gronden te vervreemden en te verpanden, steeds was daartoe vooraf's Vorsten toestemming schriftelijk te verzoeken. Had deze geen bezwaar (bijv. waar het gold om de kosten van een lijkverbranding te bestrijden) en vond hij geen aanleiding om het land voor den tusschen partijen overeengekomen koopsom over te nemen, dan machtigde de Vorst den requestrant zich tot den djedjeněnggroot-zegelbewaarder te vervoegen, ten einde van dezen een rechtsgeldige akte (lěkita) te erlangen. Vervreemding zonder voorkennis van den Vorst had, bij ontdekking, onherroepelijk naasting (tjampoet) ten gevolge. Ter voorkoming dat de triwangsa zich te gemakkelijk van hun djaba-grondbezit zouden ontdoen ten gunste van rijkgeworden Sasaks der volksklasse,

1) Vgl. Adatreohtb. XV blz 226.

) Vgl. Adatrechtb. XV blz. 303 vig. 
had de Vorst bij edict (pěswara) ${ }^{1}$ ) een maximum-prijs vastgesteld, voor welken de grond door dgl. soedra's mocht worden gekocht, een maximum zoo laag, dat daarvoor wel niemand zijn grond aan een dgl. kooper zou afstaan; daarentegen was grondovergang tusschen triwangsa's onderling aan geen grens gebonden. Bij versterf ging djaba-bezit op de erfgenamen over buiten bemoeienis van den Vorst, regel was trouwens dat dgl. landerijen familiebezit bleven wijl in de Balineesche samenleving de familieband zeer hecht is: slechts zelden ging men tot boedelverdeeling over, al gebeurde het bij aanzienlijke familiën dan wel dat 's Vorst beslissing werd ingeroepen om een einde te maken aan getwist. Dit grondbezit der geprivilegieerde klassen was vrij van vorstendiensten of andere - lasten; padjeg of oepeti toch was evenmin als ajahan vereenigbaar met het vol genot dat den triwangsa's als vrije mannen van hun landerijen toekwam. Te voornaam als zij zich achtten om hun veld zelf te bewerken, lieten zij den landbouw over aan hun slaven of aan Sasaks der volksklasse. ${ }^{2}$ ) Wel werden deze sawahs getroffen door een waterrecht, de soewinih ${ }^{3}$ ): de Vorst was nl. ook eigenaar, albeschikker over het water in rivieren en bronnen, en opstuwing daarvan was mede aan zijn vergunning gebonden, en het was in deze heffing, dat Anak Agoeng Madé, 's Vorsten beruchte tweede zoon en gevaarlijke mededinger naar de troonsopvolging, zijn kracht zocht, maar tegen de padjeg van 150 tjek ǩls stak deze soewinih van eenige zware bossen padi nochtans zeer voordeelig af; bovendien kwam dit waterrecht neer speciaal op de bewerkers, de pachters der djaba-landerijen, evenals de verplichting om in waterschapsdienst de dammen, leidingen en wegen te onderhouden, waarbij de sawah betrokken was te achten.

Met voordacht wordt hier in aansluiting bij de terminologie van Ind. St. 1906 no. 431 de uitdrukking erfelijk individueel

1) F. A. Liefrinck, De landsverordeningen der Balische Vorsten van Lombok, II blz. 210 vlg,

2) $\mathrm{Na}$ de regeling der grondgeschillen is op Lombok de landrente ingevoerd tot een aanmerkelijk lager bedrag dan voorheen, doch daarbij is het djaba bezit belast geworden en zulks, na een overgangsperiode, op gelijken voet als het overig bezit; in het nieuwe systeem wordt deze landrente tusschen bezitter en bewerker gehalveerd.

3) Dit waterrecht, oorsponkelijk dienende tot goedmaking van gemeenschappelijke kosten, o. a. voor het groote jaarlijksche offermaal, doch naderhand geworden tot een landsinkomst, is onder ons bestuur aanstonds opgeheven. 
bezit gebezigd en niet die van eigendom: hetgeen, zeide o. a. een poenggawa als I Dewa Gede Pinatih, voorwerp van eigendom is, is niet de grond, wijl deze den Vorst toebehoort, maar het bewerkingsrecht, het genot en de bevoegdheid om die te vervreemden. Vraagt men, waar dit Lomboksch vorstenrecht is beschreven, dan moet ik het antwoord schuldig. blijven, maar erkend werd het algemeen; schoorvoetend door de Sasaks, inzonderheid die van Midden- en Oost-Lombok, die zich gaarne beriepen op Selaparangsche heugenissen en verder hun padjegvrije petjatoe's gaarne poesaka noemden, hetgeen zij ook waren, maar niet in den zin van eigendom; volmondig erkend werd het door de Balineezen, de hoogsten in den lande niet uitgezonderd. De Vorst is in hun oog eigenlijk de belichaming der godineid op aarde. Al was de laatste Vorst van Lombok slechts een voorname Wesya, allen gehoorzaamden hem, noemden hem Ida Anakké Agoeng; en al was het ontwijfelbaar juist, dat de Vorst zijne hooge rijksgrooten, de geleerde priesters en heilige mannen met groote onderscheiding bejegende, hen raadpleegde, rijke geschenken toebedeelde, zelfs hen min of meer als gelijkwaardig behandelde, en verder niet willekeurig doch zooveel mogelijk overeenkomstig de oude instellingen en naar billijkheid strevend regeerde, zoodat het verkeerd zou zijn al te letterlijk die bijna goddelijke almacht voorop te stellen, - binnen redelijke grenzen bevat de Balineesche zegswijze volkomen waarheid welke zegt: ,agama alah déning péswara, p̌̌swara alah déning pekajoenan", d.w.z. de godsdienstige wet zwicht voor 's Vorsten edict, 's Vorsten edict wijkt voor 's Vorsten welbehagen. Voor ons gezag is dit hooge standpunt van niet geringe beteekenis geweest; zonder het rechtsbewustzijn der Balineezen te krenken, zijn wij daardoor in staat geweest zelfs tegen de heilige wet in te gaan, waar ons rechtsgevoel dit eischte.

Midden in het vruchtbaarste deel des lands had de Vorst zijn zetel gevestigd in de sterke koningsstad Tjakranegara, het oude Singasari. Vier 's nachts gegrendelde poorten (djebag) gaven toegang Noord, Oost, Zuid, West, langs belommerde, breede heerbanen, die elkander rechthoekig sneden in het hart der stad. Bij dezen viersprong lagen 's Vorsten poeri's, ommuurd en veilig bewaakt; des nachts mocht geen man op verbeurte 
van zijn leven verder komen dan het petandakan-voorplein, des daags hield de Vorst gemeenlijk twee maal audiëntie. Hier was hij regeerder, wetgever en rechter in hoogste instantie. In zijn edicten assumeerde hij zich wel zijn zoon, den troonopvolger, soms ook diens broeder Anak Agoeng Made. Bij de behandeling der landszaken luisterde hij aandachtig naar den raad zijner aanzienlijkste bahoedanda's, I Goesti Njoman Wanasara, I G. Made Wanasari Padjang, I G. Njoman Kaler en I G. Gede Oka, maar toch waren dezen in het rijksbestel niet meer dan door afkomst, aanzien, rijkdom en talrijkheid van volgelingen en onderhoorigen de hoogsten onder de poenggawa's ; werden hun gewichtige zaken ter regeling of beslissing toevertrouwd, zoo geschiedde dit telkens krachtens bijzondere opdracht. Het dagelijksch gerechtshof was dat van de djęjeněng's of djaksa-negara, waarvan er twee dagelijks zaten in den voorhof van den Méroe of rijkstempel te Tjakranegara, twee anderen in die van het aangrenzende Mataram; dezen berechtten schuldzaken, de gewone overtredingen van 's Vorsten edicten, en hadden de gewichtiger zaken aanhangig te maken of voor te bereiden, over welke, bij aangelegenheden, de heilige geschriften rakende, geleerde pedanda's en anders voorname poenggawa's werden geraadpleegd, maar het was de Vorst zelf, die in gewichtige zaken het vonnis velde. Waakzaam ging zijn oog over het gansche land, een ieder houdende binnen de perken van recht en zede, de ordening des lands handhavende, zooals de religie'uze wet die voorschreef, aanvullende bij eigen edict, waar behoefte aan regeling bestond.

In de koningsstad geen zweem van autonomie. Vorstelijk regelmatig verdeeld in 4 kwartieren, elk kwartier in wijken, elke wijk in woonerven van een vaste afmeting (tenminste voor den gewonen man), was Tjakra geheel gebouwd op 's Vorsten grond. De bewoner had het gebruik van zijn erf (karang), maar niet den eigendom er van. Leegvallende erven kwamen ter beschikking van den rama desa ${ }^{1}$ ), den Balineeschen groote, die in het betrokken stadskwartier met het toezicht daarover was belast in verband met diens plicht tot inning van de woonerf-

1) In zekeren zin mag men Tjakranegara beschouwen als een Balineesche desa, waarover, met de meroe als middelpunt, onder den Vorst de 4 rama-desa gingen met de verschillende klijang bandjar in de wijken, waaruit hun kwartier was samengesteld.

Dl. 81. 
belasting (salarang karang), welke strekte tot goedmaking van de uitgaven voor het jaarlijksche, groote offerfeest in de Méroe der stad. Overigens beteekende diens functie niet veel, want noch met de veiligheid, noch met het onderhoud der wegen in Tjakranegara had de rama desa te maken; dat was de zaak der poenggawa's, wier onderhoorigen buurtgewijze bijeen woonden en die als zoodanig te zorgen hadden voor de wegen, waaraan zij gelegen waren, en voor de veiligheid in hun buurt of wijk uit hun midden eenige wachters, zgn. langlang tanda, hadden aan te wijzen, die voor de politiezorg in dien engen kring verantwoordelijk en tot belooning daarvoor ontheven waren van de zooeven bedoelde wegdiensten. Voor Tjakranegara en Mataram waren van 's Vorstenwege bovendien nog stadswachten ingesteld (langlang), maar dezen waren toch meer volgelingen van een drietal poenggawa's, bij wie zij wacht hielden ten einde te allen tijde, overdag of des nachts, beschikbaar te zijn, hetzij voor staatsiegeleide dan wel het overbrengen van brieven of voor het opvatten van misdadigers en het patrouilleeren 's nachts; zij waren gewapend, werden om de 5 of 10 dagen afgewisseld, en genoten, boven en behalve het genot van een padjegvrije těnah sawah, tijdens hun wachtdienst teerkost van hun pambekel. Elke wijk vormde in Tjakra min of meer een geheel, een gemeenschap van aan elkaar verwante of uit eenzelfde plaats van herkomst stammende personen. Voor onderlinge sociaal-religieuze buurt-belangen, inzonderheid met het oog op de lijkverbrandingsfeesten, vormden dezen een eigen gemeenschap (bandjar) met reglement ${ }^{1}$ ) en kas, veelal tevens met een wijkgebouw, waar eenmaal in elke maand van 35 dagen het signaalblok hen ter bijeenkomst opriep ter bespreking van gemeenschappelijke belangen onder een uit hun midden zelf gekozen hoofd. Naast deze bandjar-gemeenschap, maar toch ook wel vaak min of meer hiermede samenvallend, stond de buurtvereeniging der onder een afzonderlijken klijang gestelde groep van dienstplichtige Balineezen der volksklasse: deze klijang pengajah werd evenwel aangesteld door den betrokken poenggawa of pambekel na raadpleging van de eigen groep, eene aanstelling, die met betrekking tot 's Vorsten wapendragende manschap, wel eens aan diens goedkeuring werd onderworpen.

1) Vgl. Adatrechtb. XV blz. 261-297. 
Vormde Tjakranegara, hoezeer uiteenvallende in wijken van zeer voorname Balineezen naast andere van de volksklasse, nog eenigermate een religieus-sociale gemeenschap met tot middenpunt den desa- of rijkstempel, den Méroe tegenover 's Vorsten poeri, - buitenaf ten platten lande ontbrak een zoodanig centrum, en stonden in eenzelfde vestiging de bij elkander gebouwde buurten of goeboeg's los naast elkaar. Balineesche nederzettingen had men daar slechts weinige, althans van blijvenden aard; de meeste Balineezen woonden in de vier groote steden, en begaven zich voor het padiseizoen naar hun velden, om na den oogst weder terug te keeren. In deze dorpen, zooals bijv. Tanahbět, dat uit twee bandjargemeenschappen bestond, had elke wijk een eigen, en was er geen gemeenschappelijke tempel. Bij de Sasaks was in verband met hun veel eenvoudiger geloof en hun lagen stand het gemeenschapsleven veel minder georganiseerd, al hadden dezen ook wel wijk- en buurtgemeenschappen, die zich om de kleine moskee en verder om het eigen buurtbelang groepeerden. Maar in den regel vormden zij buurten van onder eenzelfden poenggawa gestelde vorstendienstplichtigen van in den regel hoogstens vijftig gezinnen, dicht opeen gepakt in morsige kampongs achter smerig gepleisterde kleimuren wonende, en geheel los van elkaar staande. Oudtijds hebben ongetwijfeld de groote Sasaksche vestigingen in WestLombok désa's gevormd, maar die tijd was lang voorbij; er was niets meer van een eenheid te bespeuren, de dorpen waren verbrokkeld (mapetjah) in goeboegs, die elk een eigen buurtgemeenschapje vormden, van te weinig beteekenis om daaraan de Javaansche benaming van desa of inlandsche gemeente toe te kennen. Aldus bijv. Seséla, klaarblijkelijk een oude Sasaksche desa, thans bestaande uit niet minder dan negen goeboegs van dienstplichtigen, elke onder een eigen klijang en deze weder gesteld onder een afzonderlijken poenggawa. Aan den ouden tijd herinnerde het heilige graf van een Datoe van Selaparang, waaraan eenig wakapbezit in sawah en tuin onder een djero paš̌k verbonden was. Maar elke dezer goeboeg's, Seséla-kebon-roesak, S. désa, S. barat-koeboer enz. was het ressort van een afzonderlijken poenggawa; elk buurthoofd inde de padjeg en oepeti uitsluitend van zijn eigen dienstplichtige onderhoorigen en bemoeide zich alleen met zijn eigen volk; slechts was in het belang van politie of justitie verordend, dat, indien in eene 
vestiging slaven woonden, die te gering in aantal waren om een eigen klijang sepangan te hebben, de klijang pengajah in het belang van rust en orde ook over deze onvrijen moest gaan.

In het vorenstaande ligt opgesloten, dat buiten het kampongcomplex der aaneengesloten goeboegs en woonerven het begrip desa-gebied illusoir was. In West-Lombok was dit inderdaad het geval. Aan den kampongrand grensde gewoonlijk een strook grond met bamboe of eenig geboomte begroeid, die bestemd was tot uitbreiding, zoo noodig, van de nederzetting en als „tagtagan goeboeg" mitsdien tot deze behoorde. Maar buiten de bewoonde plekken was de zorg voor wegen en leidingen een aangelegenheid der waterschappen, waarvan de hoofden (pěkasèh) bevoegd waren om de sawahbewerkers, derhalve ook die der djaba-bezittingen, op te roepen, naar den maatstaf van één man per twee těnah sawah. Het waterschap had zijn eigen instellingen: de zorg voor dammen en waterloopen, het jaarlijksch offermaal, de verplichte hanengevechten, en de buurthoofden hadden op dit gebied geen taak, alleen om de waterschapshoofden behulpzaam te zijn.

Zoo was het in West-Lombok, het vruchtbaarste en best bevolkte deel van het eiland, waar de Balineesche Vorst en zijn Karangasemsche volgelingen zich stevig, hadden gevestigd, steden stichtend en waterwerken aanleggend, waardoor de rijkbevloeide sawahvlakte om Tjakranegara een uitstekend bebouwd, maar tevens geheel verbalineesd landschap te aanschouwen gaf: buiten de hoofdvestigingen werd het platteland beheerscht door het waterschapsbelang, dat de oude desa-gebieden had opgeheven, en van de oude Sasaksche adellijke geslachten was niets meer over, behoudens enkele groepen van eenigszins bovens de heffe des volks uitstekende Sasaksche parěkans, volgelingen van den Balineeschen Vorst. Buiten West-Lombok was het eenigszins anders. Daar lagen nog slechts enkele Balineesche vestigingen ${ }^{1}$ ) als even zoovele wachtposten; overigens

1) Een zoodanige post was bijv. die in het landschapje Pringgabaja van een Djĕro Bagiarta Pakandĕlan, die met zijn onderhoorige kaoela uit WestLombok naar het z.g.n. Dangin Djoering was verbannen, wijl zij geweigerd hadden om overeenkomstig den last van hun poenggawa Goesti Gede Sranta vorstendienst in de poeri (maèbat) te praesteeren. Eene dergelijke opzegging van gehoorzaamheid (mětilas) werd steeds op last van den Vorst onderzocht en, als het verzet ongegrond werd geacht, naar bevind van zaken gestraft bijv. door verbanning, zooals in het onderhavig geval. De verbannenen waren in het bezit van dienstplichtig domein gesteld. 
was alles Sasaksch land. Daar waren nog overgebleven de antiek-Javaansche desagebieden met vaste grenzen, binnen welke de hoofdnegorij (desa) lag benevens de van daaruit gestichte gehuchten (padasan) met het omliggend territoir (pajar) van bosch en veld; hier stond de landbouw over het geheel nog op een primitief peil en de waterschapsorganisatie ontbrak, wijl de sawahs er meest van regen afhankelijk waren. De padicultuur werd er nog veelal op droge gronden, dikwerf op zwervende velden (rao, oma) gedreven. Wel was het zelfstandig Sasaksch landschapshoofd, de pambekel, erfelijk gekozen uit den hoogsten Sasakschen adel in de desa, hier reeds meest vervangen door een Balineeschen poenggawa, die in deze desa een gemachtigde (perkanggo) had, wijl hij eigenlijk te Tjakranegara of te Mataram woonde en daarom in zijn Sasaksche provincie slechts een pasanggrahan had, maar in dezen perbekel was nog altijd wat overgebleven van de voormalige landschapshoofden ${ }^{1}$ ): bijgestaan door een klein-djaksa, die tevens als schrijver fungeerde en als zoodanig de lontar-bescheiden voorzag van een ambtszegel met den naam der desa er in, nam hij kennis van alle politie- en justitie-zaken, de groote opzendend naar Tjakranegara, in de kleine zelf beslissend, voorts lontar akten opstellend voor plaatselijke transacties. Onder dezen perbekel stonden de klijangs van de diverse groepen, waarin naar rang en stand de bevolking voor 's Vorsten dienst gerangschikt was, groepshoofden, wier functie in beginsel ook erfelijk was, behoudens raadpleging en goedkeuring der voornaamste onderhoorigen. Het getal dezer groepshoofden was niet gering: Pringgabaja bijv. had in de hoofdnegorij niet minder dan negen klijangs, die elk met hun onderhoorigen in een eigen kampong of goeboeg woonden; twee over de groepen der wapendragende adellijken of perwangsa's; twee over gelijksoortige, met geweer of lans bewapende loepoet's, personen die als vorstelijke wapendragers eenigermate waren onderscheiden (wisoeda) boven de leden der volksklasse, de djadjar karangs, tot welke zij eigenlijk behoorden, en die, om hun krijgsdienst, waren ontheven

1) Deze Sasaksche desahoofden zijn als zoodanig het best te vergelijken met dè margahoofden van de Lampongs en Palembang. Zij behooren tot het oudste adellijke geslacht, tot dat van den stichter der desa, en bij den aanleg van nieuwe vestigingen zijn het in den regel dezer afstammelingen geweest, die daarbij de leiding hebben gehad. 
- vandaar hun naam loepoet - van de gewone ajahanverplichtingen, welke op den gemeenen man rustten; verder één klijang over de als wachters of als boodschappers fungeerende langlangs, en ten slotte nog vier klijangs over de groepen der perdjaka's, onder welken naam ${ }^{1}$ ) in dit ouderwetsche gebied de gewone vorstendienstplichtigen of pengajahs van West-Lombok bekend stonden. Al deze personen hadden een aandeel in de tot het vorstelijk domein behoorende sawahs en tuinen der betrokken desa op denzelfden voet als in WestLombok; de perwangsa's en loepoets genoten als bevoorrechte dienstplichtigen vrijdom van padjeg voor één of een halven tenah sawah elk - hadden zij meer grond in bewerking, dan betaalden zij daarover de gebruikelijke landrente - , en de perdjaka of gewone dienstplichtigen deelden in de padjeg of oepeti naar de uitgestrektheid van hun bovendien met vorstendienstplicht bezwaarde gronden.

Langzaam maar zeker geraakte Midden- en Oost-Lombok dieper onder de Balineesche overheersching. De eerste verslechtering was het stellen van den Sasakschen pambekel onder een Balineeschen poenggawa, hetgeen gepaard ging met het opleggen van werkelijken dienstplicht aan alle weerbare manschap en in. voering van 's Vorsten grondlasten, zij het aanvankelijk op den zeer schappelijken grondslag van 1000 kèpèngs per 1600 patjeraken sawah als oepěti. Naar gelang van omstandigheden, bij elken zweem van ontrouw of verzet, verzwaarde de Vorst zijn druk. Het is waar, dat in deze afgelegen streken, zonder scherp Balineesch toezicht, nogal eens het een en ander gebeurde, dat tegen de ordening van den Vorst inging: Sasaksche adellijken beschouwden zich nog wel als bezitters van de hun gelaten gronden en beschikten daarover, soms zelfs, bijv. ter verpanding, met voorkennis van hun Balineeschen pambekel, doch tot 's Vorsten domeinrecht deed zulks niet af; het overlijden van aanzienlijke Sasaksche hoofden was den Vorst steeds een

1) Op Java werden voorheen met dezen term perdjaka (paradjaka of kanoman) of in Maleische vertaling als boedjang aangeduid de Cheribonsche heerendienstplichtigen, welke Daendels aan den grooten postweg door de Preanger te werk gesteld heeft [Plakaatb. XIV blz. 701 op 5 Mei 1808]. Reeds van het einde der $\mathbf{1 7}^{\circ}$ eeuw af waren deze perdjaka's op de Bataviasche suikermolens werkzaam krachtens aanwerving in Cheribon, blijkbaar met vergunning zoo niet op last van de Regeering, - een gebruik, dat door Daendels werd verboden (t.a.p. blz. 709 op 8 Mei 1808). 
welkome gelegenheid om weder onder zijn macht te brengen wat hem was verborgen gehouden. Ook waren het niet alleen Sasaksche hoofden, die hun meester te kort deden, ook Balineesche poenggawa's waren er, die voor den Vorst landzaken verheimelijkten, ten einde zelf daarvan de vruchten te plukken. Meermalen zijn sawahontginningen verzwegen, waarvan de padjeg of oepeti door den poenggawa voor zich werd gehouden; deze werd bij ontdekking door den Vorst eenvoudig aan zich getrokken, de poenggawa met zijn ongenade bedreigd. Elders waren het Balineezen die te zamen met Sasaks een uitgestrektheid woesten grond in sawahs herschiepen; ook deze gronden werden domein, alleen mochten de Balineezen dan wel een gedeelte padjegvrij als petjatoe behouden. Met het aanleggen van gaga's of rao's op woeste gronden liet de Vorst zich evenwel niet in. De opbrengst van dgl. tijdelijke rijstveldjes was te gering om ze te belasten; slechts was het gebruikelijk, dat de aanleggers daarvan zich verstonden met den pambekel en dezen de recognitie van eenige padi-bossen opbrachten, de zgn. gondja ten bedrage van bijv. den elfden bos, terwijl bij het inzamelen van waardevolle boschproducten een gelijksoortige adatheffing in zwang was. Eene dgl. recognitie, gelijk aan de Javaansche pamèsi, bleef intusschen slechts aan het plaatselijk hoofd voorbehouden, zoolang den Vorst goed dacht: reeds was van de katoenaanplantingen langs Lombok's Noordkust de gondja in natura grootendeels omgezet in een domein-oeperti in kèpèngs.

Aldus was in algemeene trekken het domeinrecht op Lombok. De Vorst-albeschikker, Sang amawa boemi, gaf van zijn grond uit aan zijn trouwe medestanders, volgelingen en onderdanen naar de mate van zijn waardeering hunner diensten: aan de hoogsten in den lande het vol en onbezwaard genot daarvan met de bevoegdheid om daarover voor gepaste doeleinden vrijelijk te beschikken; aan zijn trouw volk het onbezwaard genot van een dienstplichtig, onvervreemdbaar, echter erfelijk aandeel; aan de laagste klasse, de onderworpen Sasaks, een gezinsaandeel, erfelijk maar onvervreemdbaar, en bezwaard met een domeinpacht, die berekend was naar den grondslag van halfbouw, verminderd ten gunste des bewerkers met zooveel als een gepaste vergoeding geacht werd voor de door den Vorst geëischte vorstendiensten. 


\section{OUD JAVA.}

Wanneer het licht opgaat over oud-Java, ziet men den Vorst trotsch door de stad rijden, gezeten op zijn staatsieolifant, omgeven door zijn lijfwacht, terwijl het volk nederig langs den weg hurkt; of troonen op den gouden dampar, zijn rijksgrooten audiëntie gevend binnen zijn ommuurde poeri. In de hofstad krioelt het van vazallen en rijksgrooten met hun gevolg, van dienaren, hooge en lage, die zorg dragen voor stad en land, voor 's Vorsten schatkamers en padipakhuizen; van geestelijken van diverse gezindten, die in talrijke tempels den eeredienst leiden.

Eenige eeuwen later heerscht te Madjapahit de dynastie der alverwinnende Bra-Widjaya's, die de oude landsinzettingen handhaven, welke het landvolk gehoorzaam betracht; en wien de opvolgende Gadjahmada's na volbrachte vloottochten de schatting van de verschillende rijken in den Archipel komen aanbieden ${ }^{1}$ ). Overal verrijzen heiligdommen, prijkend met bewonderenswaardige beelden en rijke reliëfs. Vrome aanzienlijken verwerven 's Vorsten sanctie op door hen ingestelde religieuse stichtingen, staande op grond die nu eens van ouds in hun bezit dan weer gekocht is van anderen, en verwerven daarvoor vrijdom van allerlei lasten en verplichtingen. Het is maar al te vaak onduidelijk wat die termen beduiden, maar zooveel is zeker dat het in Madjapahit niet ontbrak aan rijkslasten (radjakarja, poetadjènan) van allerlei aard: diensten voor het bakken van steenen, herstellingen in Madjapahit's havenplaats Tjanggoe enz. en geldelijke belasting van het landvolk - de palawang, - dan wel in de steden van ambachtslieden of in de plaats daarvan oogstheffingen. Ik vermoed dat die Javaansche alleenheerschers beschikt hebben over ontzaglijke uitgestrektheden domeinsawah ter spijziging van hun eigen poeri's, ter apanageering hunner grooten en dienaren, en instandhouding der voornaamste tempels, maar zekerheid ontbreekt.

1) Gadjahmada's palapa-eten [Pararaton ed. $1920 \mathrm{blz} .128,141$ ] is mij een zinspeling op alap-alappan en daardoor een zinnebeeldige voorstelling van diens veroveringstochten in den archipel. Hetzelfde geldt, meen ik, van de verhalen in welke kalapa's worden leêggedronken of klapperboomen worden getapt; vgl. Babad Tanah Djawi blz. 115/6, waar dèrès dan ook in beeld brengt: met het $\mathrm{zwaard}$ veroveren. 
Of de bekende plaats in de Koetaramanawa: ,indien iemand zijn land verpandt, vervalt dit pand nooit, want het land is eigendom des vorsten, het blijve slechts bij den pandnemer", inderdaad wijst op een alomvattend domeinrecht, berustend bij den Narendra-Oppervorst, terwijl de met een aandeel daarin begiftigde personen slechts het genot van den bodem hebben nevens den eigendom van hetgeen daarop gebouwd is, verpandbaar, bij de bezitters der hoogste kasten, maar overigens dienstplichtig domein, - ook dit moet dus in het midden blijven. Het deze uitspraak behelzend lontarhandschrift was afkomstig van Bali, en wijl de Nagarakrtagama verhaalt, dat Bali op last van Madjapahit's Vorst naar het voorbeeld van Java georganiseerd is geworden, zou die Koetara-manawa-tekst een gegeven voor Java kunnen bevatten, doch wederom: wij missen zekerheid. Toch zal men m.i. wijs doen nimmer uit het oog te verliezen dat Bali onder Madjapahit door Gadjahmada is onderworpen; voorts dat Madjapahit is gesticht op de puinhoopen van Daha en Toemapel; dat Madjapahit oorloogde tegen opstandige vazallen, tegen Soenda, - en een krachtens verovering als buit verworven, haast onmetelijk domein in land zou daarom ons niet behoeven te bevreemden.

\section{BANTAM.}

De traditie schrijft aan den oudtijds ook op West-Java bekenden term tjatjah ter aanduiding van een in bouwland gezeten, op eigen erf wonend, aan vorstendienst dan wel aan oogstheffing onderworpen huisgezin een hoogen ouderdom toe, en verhaalt o.m. dat reeds onder het Demaksch sultanaat het getal tjatjahs van zeker landschap als de grondslag was aangenomen voor alle materieële en geldelijke lasten als ook voor de vorstendiensten, gelijk later onder Mataram over zoo goed als gansch Java het geval is geweest. Zooveel is zeker, dat de ouderwetsch-Javaansche term djoeng, die bij het Mataramsche landelijk stelsel als vlaktemaat-tevens padjeg eenheid algemeen gebruikelijk was, ter aanduiding van een zekere sawah-uitgestrektheid, nog in 1222 Hidjrah of 1807 A. D. wordt aangetroffen in een Bantamsche sultanaatsakte, en dit behoeft ons niet bijzonder te verwonderen, wijl Bantam's eerste Mohammedaansche Vorst het land veroverd en gekoloniseerd heeft met krijgsvolk, dat hem tot bijstand was gegeven door zijn zwager, den Pangeran van Japara-Demak. 
Te Banten-Girang, gelegen aan de Kali Banten of Daloeng, zal men wel mogen zoeken het Pakoewan-Padjadjaransch perdikangebied van Soenda Sembawa met het heiligdom daarop, stichting van den Ratoe Adji Çri Sang Ratoe Dewata, op wien betrekking hebben de koperen plaatjes van Kebantenan ${ }^{1}$ ). In de traditie is Banten Girang met de Goeha Tembaga aan de Kali Daloeng (of: Banten) de woonplaats van twee monniken (adjar) Ki Djong en $\mathrm{Ki} \mathrm{Djo}$, die bij de komst van Maolana Hasanoedin op diens bevel den Islam aannemen en vervolgens tot gids strekken bij diens tocht naar het binnenland, waar Poetjoek Oemoem met

1) Vgl. laatstelijk Pleijte in T.B.G. 53 blz. 168 vlg. Een in 1919 door R. Hasan Soemadipradja, Wedana van Mr. Cornelis ingesteld onderzoek bracht aan het licht ${ }_{n}$ dat de persoon, naar wien de kampong Kabantĕnan „wordt genoemd, van Bantam afkomstig was - een uitgewekene, toen er "in Bantam oorlog was." Deze persoon, die te K. begraven is waar zijn graf "kramat" heet, staat bekend onder den naam van Oejoet, en het was in het huis van diens kleinzoon $\mathrm{Ki}$ Lidoeng op het erf van de kramat, dat in $1867 \mathrm{bij}$ het zoeken naar de volgelingen van $\mathrm{Ki}$ Baïrah [te Tamboen] de koperen plaatjes werden geronden, welke Raden Saleh vervolgens aan het Batav. Gen. deed toekomen. Deze plaatjes stonden te $K$. bekend onder den naam van "koebriek", hetgeen bij de Inlanders te Batavia z.v.a. eigendomsakte [waarsch. $=$ koopbrief $]$ schijnt te beteekenen. Bij deze herkomst denkt men onwillekeurig aan den Bantamschen Pangeran Poerbaja, en bij De Haan, Priangan l Person. blz. 247 noot 1, blijkt dat inderdaad dezen door de Ind. Reg. een landje aan de Tjikéas in leen was gegeven, wąr Kabantenan is gelegen; ook De Haan dacht in dit verband aan de bewuste koperen plaatjes. Het is voor mij geenszins toevallig dat Banten-Girang in een Tangerangsch kroniekje Daloeng wordt genoemd: Maolana Hasanoedin ladjeng késah mengilèn ing nagara Bantěngirang, inggih poenika Daloeng, Bantengirang poenika tempatipoen Adjar Djong....; en dat thans nog in de nabijheid van B.G. een desa Daloeng (= koperen pot) ligt, naar welke de Kali Banten ook wel K. Daloeng heet, terwijl zich in de buurt daarvan de Goeha Tembaga bevindt alsmede een bron Taman- of Waroengdaloeng geheeten; de daaraan verbonden legende betreffende een ,poenggawa moearan”, wiens graf zich in den kampoeng Kabajanan dierzelfde desa bevindt, wijst, naar ik elders hoop te behandelen, op den tijd van den overgang tot den Islam. Het is mijn berichtgever, Raden Soeriadiningrat, te Bantam niet mogen gelukken iets terug te vinden van de in de koperen plaatjes vermelde rivieren plaatsnamen; alleen valt de aandacht op Sambawang [plaatselijk Siambawang?], een steile hoogte op den weg van Goenoengsari naar Blagendong ten Z.W. van Sérang. Waar in de koperen plaatjes het perdikan-gebied geen noordgrens heeft, denkt men onwillekeurig aan de zee als grens. Ook lijkt mij in de traditie niet te verwaarloozen, dat Poetjoek Oemoem een hoofd over „adjars" genoemd wordt en Kidjongdjo in zijn geslacht erfelijk „mardika" werd verklaard met den titel van mas, agoes en ěntol: in Bagelen bestond nog een herinnering aan een landsindeeling in "domas"-ressorten, elk onder een kleinen prijaji met den titel van Ki ĕntol, en wellicht heeft iets 
zijn 800 adjars woont aan den voet van den Poelosari. In de Sadjarah Banten is Ki Djongdjo een poenggawa van Pakoewan, die komt toekijken, wanneer Maolana Hasanoedin met Poetjoek Oemoem een hanengevecht houdt onder een waringin aan den voet van den Karang ${ }^{1}$ ). Deze plek is nimmer vergeten; hier verhief zich de overoude, breedvertakte waringin dien de Resident Buijn in 1846 door de bevolking liet omkappen, wijl deze bij onrust in het gewest immer een rol vervulde; en, dat hier tusschen dezen berg en den Poelosari een belangrijke nederzetting van Pakoewan-Padjadjaran heeft gelegen - vermoedelijk de zetel van een entol over een domas-landschap, ${ }^{2}$ ) - mag men wel afleiden uit de Hindoe-Soendaneesche oudheden, een Nandi, een Ganesa en een Doerga, welke alhier in een bosch bij de voormalige districtshoofdplaats Tjimanoek zijn gevonden. Op deze Tegalpapak dan, bij Kadoehèdjo aan den weg van Pandeglang naar Menès en Tjaringin, vond het allegorisch bedøeld hanengevecht plaats, waarin de witte (d.i. mohammedaansch reine) kemphaan van Hasanoedin zegevierde over dien van tooverstaal (wěsi lan wadja), welken Poetjoek Oemoem door de kracht van zijn verbeelding had gecreëerd. Na de zege werden de adjars afgebracht naar Bantěn Girang, waar zij de pakoewon voor den Maolana bouwden en onderwezen werden in den Islam òm daarna naar den Poelosari te worden teruggezonden. Onomwonden noemt de Wawatjan Hadji Mangsoer hen «bojongan», krijgsgevangenen, die vervolgens het bosch moesten omhakken, waar Soerasowan, de kraton van Hasanoedin, werd opgetrokken, en met deze Bantamsche overwonnenen zijn dan wel vereenigd de later ook naar den Karang gedirigeerde OostJavanen, die Soenan Goenoeng Djati in 1546 uit Pasoeroean

dergelijks in Soendaasch Bantam bestaan, nl. naast zoodanig aan 's Vorsten lasten onderworpen gebied de perdikan-stichting, waarvan de koperen plaatjes gewagen en waaraan de adjars Ki Djong en Ki Djo de heugenis verlevendigen. Is te Bantěn Girang een perdikan-gebied geweest met een heiligdom (sanggar) van deu Vorst er op, dan ligt een verband met de beteekenis van bantěn $=$ offerande voor de hand. Over een wellicht ouderen vorm wahanten en over de kleine grot aan de Kali Banten vgl. Dr. Hoesein Djajadiningrat, Critische Beschoụwing van de Sadjarah Banten, blz. 113.

1) De Sadjarah Banten spreekt van een waringin bij den berg Lantjar, een zinspeling op den naam Karang (lantjar = spits = karang).

') Vgl. Barros' Chiams, een voorname zeehaven van Soenda, herkend door Veth als Tjimanoek, en de traditie van een oude domas - of: 800 tjatjahs bestuursindeeling in Bagelen, T. N. I. VIII, 3 blz. 177. 
had meegebracht ${ }^{1}$ ). Uit deze volkeren stammen ongetwijfeld zoowel de Oerang Karang als de Oerang Kanekes of Badoewi's die nu nog het bergland van Bantam bevolken en waarvan Raffles ons mededeelt, ${ }^{2}$ ) dat deze Badoewi's "not (were) compelled to become converts, but it was agreed, at the same time admitted, that the number of the Rawá-ian, the name given to their little societies (lees: rawajan) should be limited to three or four»: eene aanteekening, welke tevens de verklaring bevat van hun splitsing in zgn. oerang kadjeroan en oerang penamping of kaloewaran. Waar wij van deze Badoewi's lezen, dat zij algemeen erkenden dat de bodem aan den Maharatoe toebehoort, en wij met hen wel mogen identificeeren de bergboeren, die oudtijds met betrekking tot hun persoon een patitijang of wang lawang, en tot hun rijstvelden een kiras opbrachten, welke jaarlijks den Sultan tegen het eind der Vasten in gepelde rijst werd aangeboden, daar ben ik geneigd in dit kiras een verbasterd charadj te herkennen ${ }^{3}$ ).

Ook het laagland van Bantam was in beginsel door den Islam met het zwaard veroverd gebied; zoo wist bij het grondenrechtelijk onderzoek van 1867 de bevolking nog te ver-

1) Vgl. hiervoor Not. Batav. Gen. 58 (1920) blz. 266. In T.B.G. 45, blz. 370 releveert Pennings dat door de bevolking onderscheid wordt gemaakt tusschen de Oerang Kanekes of Oerang Rawajan, die de agama Boeda belijden, en de Oerang Karang, welke de agama Soenda aankleven, tot welke tweede groep óók worden gebracht de Mènak Bongbang, in welke vermoedelijk is te herkennen het in 1630 naar Bantam uitgeweken overschot van het volk van Dipati Oekoer; vgl. Sadjarah Banten blz. 49/50. Bàdoewi schijnt een verworden wadwa of wadya., m.a.w. het eigen volk van den Bantamschen Sultan.

2) History of Java ed. 1830 I blz. 372 II 144 noot. J. J. Meijer, De Badoej's blz. 44/45 noot heeft op deze plaatsen bij Raffles niet gelet; volgens hem (blz. 11) zou Rawajan de naam van een in de desa Kanèkès gelegen, thans verlaten gehucht, zijn geweest.

3) De schrijfwijze khiraj voor charadj vindt men in Britsch-Indië, zie Neil B. E. Baillie, The landtax of India (1853). - Volgens Van Baak zijn Menes, Tjimanoek en het grootste deel van Lebak eerst in het laatst der 18 de eeuw tot den Islam overgegaan; zie Eindres. III bijl. blz. 169 en 170. Dezelfde deelde mede, dat in den Sultanstijd de belasting voor de abdi's bet dubbele bedroeg van hetgeen een mardika betaalde; dit doelde op de palawang van eerst 8 , later 16 , toen 32 en ten slotte 64 duiten 'sjaars per gezin; daarentegen was voor beide categorieën daarnaast verplichtend één kiras $=2 \frac{1}{2}$ kati rijst. Men mag aannemen, dat deze inededeeling bepaaldelijk sloeg op Lebak, waar V. B. Ass. Resident was, het ver van de Sultansstad gelegen, weinig vruchtbaar bergland van Bantam. In het Noorderregentschap, zegt Van Bak, werd van de sawahs $5 \frac{1}{2}$ Reaal per bouw betaald, 
halen dat, toen het over de ten zuiden van Pontang gelegen desa Ragas staand hoofd Rengasdjati weigerde zich te bekeeren, hij vervolgens werd beoorloogd, en, na de overwinning, zijn volk tot abdi d.i. rijksslaaf werd verklaard, terwijl de als "poeraja» d. i. buit aangemerkte sawahs hun wel is waar gelaten werden, maar onder verplichting daarvan een zware belasting op te brengen. En hiermede is volkomen in overeenstemming de toestand, in welke Bantam's bevolking zich bevond toen bij de Eerste Schipvaart de Hollanders het eerst met deze in aanraking kwamen ${ }^{1}$ ):

"De bouwluyden in Java zijn deghene die 't landt van den Coninck ende andere Heeren hueren, ghelijck alhier te lande, daervoor betalende, naer dat sij veraccordeert zijn, 't zij een partije Rijs of Caxas: oock dese mits tselve betalende moghen soo 't haer belieft, op een ander gaen wonen, ende dese worden Captivos del Rey ghenaempt.

«... Daerenboven hebben de edellieden, rijke burgers ende kooplieden hunne hoeven ende landen buiten de Stad, daar zij hunne Slaven toe hebben, die alles bearbeiden en brengen hunne heeren allerlei vruchten als peper, rijst, cocos, oock hoenderen, geiten of diergelijken in de stad. Zij hueren ook zelven wel de landen... Andere die haer heeren dienen, hebben cost en cleeren sonder meer. Daer zijn noch andere, die 6 dagen wercken voor haer heere, ende daarnae 6 daghen voor haer ende haer huysghesin ${ }^{2}$ ), tsij dattet vissers zijn oft andere, waerin sij trouw moeten wesen; want indient bevonden worde datter yet van 't ghewin wech gegeven oft afgenomen ware, souden in groot lijden comen, 't zij dan aen een ander vercocht, oft in eenen block ghesloten».... "De kinderen die van dese slaven comen, worden den heere eyghen, also wel als de ouders, ghelyck alhier de schapen ende andere beesten doen, ende moghen der mede doen wat zij willen, doch niet dooden sonder consent van den Coninck oft Gouverneur.»

Wel een duidelijk beeld van een veroverd land, voor de overwinnaars bewerkt door eene onderworpen, en ten deele zelts tot slaaf gemaakte bevolking. "Het volk, berichtte in 1867 de

1) Ed. Linschoten-Vereeniging I blz. 129.

?) Een merkwaardig voorbeeld van het in Indonesië zeer verbreid instituut eener verdeeling in half om half tusschen eigenaar en gebruiker: Javaansch maron, Maleisch bĕbĕlah pantjarian (Benkoelen bijv.) 
Assistent-Resident Van Baak ${ }^{1}$ ) met betrekking in de eerste plaats tot Lebak, was verdeeld in mardika's en abdi's; mardika's waren zij, die vrijwillig den Islam hadden omhelsd, abdi's degenen, die aan den staat onderworpen waren doch geen mohammedanen waren geworden. Er waren, lezen wij, gansche desa's abdi, zelfs in het noordelijk gedeelte van Lebak, maar vooral in het kustgedeelte, waar de Javaansche verovering de diepste sporen naliet; zoo Ragas bij Tanara, Moendoe [distr. Tjimanoek], Bodjong in Měnès, enz. Dit abdischap, de staat van "rijksslaaf», werd door Daendels opgeheven bij de domeinverklaring des lands in $1809^{2}$ ), maar ook particulieren hadden abdi's, en bij het onderzoek in 1889 tot regeling van de heerendiensten in Bantam schreef de toenmalige Controleur B. B. Engelenberg naar aanleiding van eenige in Noord-Bantam door hem aangetroffen vrijlatingsbrieven; "dit abdischap heeft tegenwoordig wel weinig te beteekenen, maar het is toch vreemd, dat onder het Nederlandsch gezag er op Java nog goesti's kunnen zijn, die hun abdi's uitdrukkelijk moeten vrijverklaren tot losmaking van den ouden slavenband." En dat die toestanden een uitvloeisel zijn geweest van debellatie, van een door Mohammedaansch-Javaansche benden tegen Soendaneesche heidenen gevoerden "heiligen krijg," dat leert ondubbelzinnig de Sadjarah Banten, die, na verhaald te hebben van de verovering van Pakoewan-Padjadjaran en van de verdeeling van het veroverd gebied tusschen Cheribon en Bantam met klaarblijkelijk de rivier Tjitaroem als grens, den term "ghanimat» bezigt, d.i de in het mohammedaansch recht gebruikelijke benaming van oorlogsbuit. Kan men, vasthoudende eenerzijds aan het feit der verovering, anderzijds gevoegelijk laten rusten of deze buitverklaring en toeëigening geschiedde krachtens oud Javaanschrecht dan wel op grond van het Mohammedaansch heilige-oorlogsinstituut, toch kan ik niet nalaten op te merken dat de Mohammedaansche theorie zulk een buit verklaren van den veroverden grond inderdaad kent; "volgens de Sjaficieten schreef Dr. Th. W. Juynboll ${ }^{3}$ ) - behoort ook de grond "tot de ghanimah, en moet $4 / 5$ daarvan na de verovering onder

1) Eindrésumé.Java III bijl. 172.

2) Plakaatb. XV blz. 850 op 24 Aug. 1809 ad. 1. - In Benkoelen was de aanduiding van orang abdi als slaaf mede in zwang.

3) Ind. Gids 1899 I blz. 240. 
"de troepen worden verdeeld... maar later deden de mos"limsche troepen vrijwillig afstand van hun verkregen rechten, «en toen werd de Sawad tot een waqf voor alle moslims geza"menlijk gemaakt. Daarom staat het ook voortaan aan den imam "volgens hen (de Sjaficieten) vrij om aldus te handelen, als de over"winnende troepen in dgl. gevallen, vrijwillig hun rechten prijs"geven ten bate van het algemeen.» Faletahan, de veroveraar van Soenda, had, verhalen de Portugeezen, den Koning van Japara tot het Moorschdom gebracht, m.a.w. deze Paseische avonturier is de leermeester van Demak's eersten sultan, diens panembahan of soesoehoenan geweest, en het lijkt mij, dat deze niet verzuimd heeft aanknoopingspunten te zoeken tusschen de mohammedaansche leerstellingen en het door zijn zgn. bekeerling als van zelf gevindiceerd oud-Javaansch recht. De Bantamsche Sultans hebben later altijd gaarne zich goede moslims getoond, getuige o. a. dat Sultan Ageng met de Bataviasche Regeering wel een bestand van tien jaar maar geen eeuwigdurenden vrede heeft willen sluiten ${ }^{1}$ ). De Javaansche vorsten deden evenwel, al werden zij moslims, begrijpelijkerwijze geen afstand van hetgeen naar de adat hun toekwam, en zoo vinden wij dan ook vermeld in de Eerste Schipvaart: "het is te Bantam een recht, so een man komt te sterven, die kinderen achterlaat, dat de Coninck komt, ende neemt het wijf met de kinderen ende 't goed naer hem, hetselve zijn eijghen, ende de moeder tot een slave makende» ${ }^{2}$ ). Dit toch is niets anders geweest dan het Balische tjampoet, het Palembangsche mandjing-instituut.

Niet al het land bleef Sultansdomein. In 1610 bijv. is het te Jakatra niet de Sultan van Bantam maar de Pangeran Widjaja Krama die bij zijn contract over den handel met de Hollanders enz. dezen voor 1200 realen van achten een te zijner hoofdplaats gelegen stuk gronds afstond, gelegen «in het Chinees quartier, groot vijfftigh vadem in de lenghte ende sooveell in de breedte offte grooter indien sulcx van noode hadden» ${ }^{3}$ ). De Sultans waren te Bantam heel wat moeilijker. "De Bantamsche Vorsten - schreef in 1787 De Rovere van Breugel ${ }^{4}$ ) - zijn,

1) De Jonge, Opk. VI. blz. LV.

2) Dit kwam eerst te vervallen bij art. 19 van Daendels' instructie voor den Sultan van Bantam in 1808, Plakkaat B. XV blz. 364 .

3) Heeres, Corp. Diplom. I blz. 86.

4) Bijdr. Kon. Inst. 1856 blz. 168. 
van de oudste tijden af, zoo jaloers op de possessie van haar grond geweest, dat niets de Compagnie meer moeite gekost heeft als het obtineeren van den vollen eijgendom op het erf, waar zij haare gebouwen tot wooningen voor haare dienaren en berging haarer negotie-goederen zetten wilde... De wet in faveure des Konings is deze ${ }^{1}$ ), dat wanneer het zijn Hoogheid convenieert, een eijgenaar van wooningen deselve moet opbreeken, indien het bamboesen ofte houten gebouwen zijn, en wanneer het steenen huyzen zijn, kan de Koning die te allen tijde volgens taxatie overnemen. - Schoon de Vorsten er zelden of weijnig gebruijck van maeken, zoo houd het nogtans den ingezetenen natuurlijkerwijs in een gedurige vreeze, en belet hen tuynen aan te leggen, of kostelijke vrugtboomen te planten, dewijl haar eigendom niet zeker is en van de willekeur van hun despoten afhangt.»

In de Sadjarah Banten is het Bantam's tweede sultan Molana Joesoep geweest, die zich bijzonder aan den sawahbouw liet gelegen liggen, rivieren opdamde, leidingen groef en wildernis in desaland herschiep. Het is de vraag of deze Molana wel werkelijk vorst is geweest, wellicht is hij nog als Pangeran Ratoe of Sultan Moeda, medebestuurder onder zijn vader, overleden, doch het feit van den sawah-aanleg zal wel juist. zijn. Dergelijke ontginningen op eenigszins groote schaal gingen de krachten van den enkeling en zelfs van het desavolk oudtijds meestal te boven; daarvoor was de beschikking over veel werkers, over padi ter spijziging daarvan en over een menigte ploegvee noodig, en dgl. sawah aanleg was daarom voorheen een zaak vooral van den vorst, de rijksgrooten en de regenten, terwijl de kleine man het veld in pacht, hetzij in padi hetzij in geld kreeg. Uit de Sadjarah Banten mag men wel opmaken dat het Sultan Agoeng van Bantam is geweest die het land, waar thans de hoofdplaats Sérang ligt, in sawahs heeft doen herscheppen, en te Soerasowan op de aloen ${ }^{2}$ de groote rijstschuur doen bouwen ter berging van de daartoe als domeinpacht verkregen padi. Omstreeks 1670 zien wij dienzelfden vorst bezig een kanaal te graven tusschen Tanahara en Pontang «om 't woeste land, aldaar leggende, totte rijstplanting te bequamen» - hij was in deze streken al van 1660 bezig, - en tot dit werk

') A. v. blz. 125 .

2) Eindrisumé-Java III bijl. blz. 173 . 
waren "geordonneert 16000 mannen en 200 weghgeloopene van Batavia», terwijl later ook de naar Bantam gevluchte Makassaren «alle door haere Crains werden geprest op Pontang te arbeyden tot het graven der vaert... (evenals) de amphioensuygers». ${ }^{1}$ ) Die vaart is het thans nog bestaande Sultanskanaal, in de nabijheid waarvan Sultan Ageng zijn ook in de historie bekende lustverblijf Tirtajasa liet bouwen, het begin tevens van een nieuwe Sultansstad, doch later in den krijg tegen de zijn zoon steunende V.O.I.C. verbrand en in de lucht gesprongen.

Aldus, lezen wij in het Eindrésumé, ontstonden veel domeinsawahs, eerst "naar men zegt, oostelijk van Serang, in de streek tusschen den grooten weg en het zeestrand, een vlakte met een kleine helling van zuid naar noord. Later geschiedde het ook westelijk van Sérang, maar steeds in de strook land tusschen het hoogland en de zee... Die sawahs, welke op last, somtijds met verstrekking van hulpmiddelen vanwege den Sultan, als hoofd van den staat, waren aangelegd, waren domeingronden, en kregen als zoodanig den naam van sawah negara.»

Deze sawah negara zijn de kern van het Bantamsch sultansdomein geweest; hierin vonden de Rijksbestuurder, de grooten, het kratonpersoneel hun ambtsvelden. Een vroege verwijzing naar dusdanig ouderwetsch-Javaansch gadoehan of leenroerig bezit - wij spreken thans meer van apanage - vinden wij vermeld met betrekking tot den zoon van den laatsten Pangeran van Jacatra. Voor de keus gesteld om gekrist te worden dan wel zijn land prijs te geven ${ }^{2}$ ), koos de Pangeran, die het gevaar reeds lang had voelen aankomen, het leven, en naar Bantam gevoerd «met zijn broeder den Tommagon met omtrent 50 personen, soo mans, vrouwen als kinderen ${ }^{3}$ ) bracht Widjaja Krama zijn verdere dagen door in de desa Ragas aan de Tjioedjoeng, waar hij ook is begraven, en zulks onder den naam van Pangeran Djampalahon, naar de plaats, waar, zegt de Sadjarah Banten, de Vorst hem een dalem had aaangeboden.» Volgens de traditie ${ }^{4}$ )

1) Daghregister op 1670 (19 en 28 Oct., 20 Nov.) en 1671 (5 Jan., 20 Nov. en 1 Dec.).

2) De Jonge IV blz. 174; het in zijn bezit aangetroffen particulier vermogen van $\pm 30.000 \mathrm{Sp}$. R. werd genaast.

3) A. v. blz. 174.

4) Eindrésumé III 1 (f), blz. 2 (a) enz.

Dl. 81. 
besloeg dit Ragas, een desa abdi, welke onder Daendels haar vrijdom erlangde, de geheele uitgestrektheid tusschen Kopo, Gempol, Sampit en Toedjoeng, terwijl een groot deel van Tjikandi er onder viel. *De soon van den voorgaanden Coning van Jacatra, lezen wij daarna bij Carpentier ${ }^{1}$ ), die dus lang obscur en als privaet persoon geleeft heeft, is bij den Pangaram weder tot staet geadvanceert met een quitesol over 't hoofft en met de helft wan sijns vaders goederen gedoneerdt. . Soortgelijk gadoehan - bezit [en dan in beginsel erfelijk, zij het niet altijd tot de volle uitgestrektheid] is ook het aan den mond van Tjioedjoeng gelegen Pontang geweest ${ }^{2}$ ), waarover tijdens onze Eerste Schipvaart de Sénapati van Bantam stond.

Er werd met dit apanage-bezit, naar het schijnt, nogal eens omgeleefd, hetgeen niet onverklaarbaar is, waar de Sultan van Bantam niet rijk was en met zijn familie nog al eens wat te stellen had. Maar de schuld lag ook wel bij hem zelf. In 1734 schreef bijv. Van Gollonesse over Sultan Djainoel Arifin: "voornamelijk maakte hij sig gehaat bij sijne Broeders en Rijxgrooten, omdat hij onder alderhande pretexten deselve van haar beste landerijen, onderhoorigen en goederen beroofde» ${ }^{3}$ ). Daarentegen getuigde in 1761 Van Ossenberch gunstig over den toenmaligen Sultan. "Sijn Majesteit, schreef hij, ${ }^{4}$ ) in den beginne van mijn komst voorgedragen hebbende de nadeelige consequentie door het onbebouwt blijven van verscheijden landstreeken, die genoegsaam ontbloot van inwoonders waren, heeft ten eersten daarin voorsien, met alomme ordre te stellen, dat een ieder moet blijven op syn woonplaats, zonder zig elders te mogen begeven, en, om den landman in sijn sobere staat tegemoet te komen, heeft $\mathrm{Zijn}$ Hoogheid haar de helfte van zijn jaarlijksche inkomste of van 't hoofdgeld quijt gescholden, mits een ieder hem zal toeleggen op het aanplanten van rijst, voornamentlijk van jonge peperranken, waar die ook maar groeijen willen». Dit hoofdgeld is wel het patitijang of wang lawang geweest, waaraan ook de Badoewi's onderworpen waren, en het is m.i. niet toevallig dat deze term nagenoeg eensluidend is met het MiddenJavaansche palawang, waarvan wij reeds in Oudjavaansche oor-

1) De Jonge V blz. 100 anno 1625.

2) Eindrésumé-Java III blz 2 noot e.

3) B. K. I. 4e R. V blz. 65.

4) A. v. bl\%. 115 . 
konden gewag vinden gemaakt ${ }^{1}$ ). En mede schijnt mij dit hoofdof huisgezinnen- dan wel deur-geld bedoeld, waar de GouverneurGeneraal Van Imhoff, met betrekking tot het eerst kort aan de V.O.I.C. overgegane gebied in Tangerang langs de $\mathrm{Tji}$ Sedanè (later de Gerěndèng genoemd) opmerkte ${ }^{2}$ ) dat de bevolking in die reservatie van 600 roeden langs de westelijke boord" (tot de Tjisawi) nog stond *onder de Bantamsche hoofden, en veel volk van deze (d.i. oost-) zijde emigreert derwaarts, omdat zij, zoo men zegt, zich daar voor een geringe som in het jaar van alle hare diensten kunnen afkoopen, hetwelk dan ook bij consequentie infereert dat die menschen tot hiertoe niet extra wel bij 's Compe bediendens moeten behandeld zijn*. Een dergelijke belasting bestond in Mataram, waar zij plaatselijk bekend stond onder de benaming van paklantang, patjoempleng of grabag, doch door ons genoemd werd hoofdgeld, terwijl zij in waarheid was een per tjatjah ${ }^{3}$ ) in geld geheven vaste jaarlijksche schatting, die in de plaats trad hetzij van de praestatie van sikep-diensten hetzij van de domeinpacht in natura. Van Baak deelt mede ${ }^{4}$ ), dat tijdens het Bantamsch sultanaat in het Noorden van het rijk eene belasting in geld werd geheven ten bedrage van $\frac{1}{2}$ reaal of 128 duiten per bouw sawah 's jaars, en het lijkt mij niet onwaarschijnlijk dat deze sawahbelasting slechts een andere voorstelling is van het evenbedoelde Tangerangsche heerendienst-hoofdgeld.

Heerendienst was uiteraard ook een Bantamsche landsinstelling. "Elk inwoonder van Bantam, constateerde De Rovere van Breugel, ${ }^{5}$ ) is verpligt tot heerendiensten aan zijn hoofd in ijder Negorij, en buijten des nog in het generaal aan den Vorst zelve». En met betrekking tot laatstbedoelde verplichting teekende Van Gollenesse aan ${ }^{6}$ ): "ten tijde (de Sultan) dat nieuwe

1) Poerbatjaraka in B.K.I. 80 blz. 282/283.

2) B.K.I. 2 VII blz. 230.

3) In Verh. Bat. Gen. I blz. 6, Korte Schets enz. door Radermacher en W. van Hogendorp leest men: „Bantam . . . Dit rijk is weinig bevolkt en heeft niet meer dan 5000 tjatjars of huisgezinnen, die men op Java ieder op twee wapendragende mannen, twee vrouwen en twee kinderen rekent'. Dit tjatjar zal men wel moeten lezen tjatjah en blijkt ook hier de beteekenis te moeten hebben van dienstplichtig (ergo bouwveldbezittend) gezinshoofd. Jacatra en Priangan stonden daar op 29.000, Cheribon op 15.000 tjatjahs.

4) Eindrésumé III bijl. blz. 173.

5) B.K.I. 2, I, blz. 116.

6) B.K.I. IVe Serie V blz. 69. 
sware gebouw in sijnen Dalm heeft laten voltooijen, (gaf) hij de werklieden niet anders als haar randsoen van rijs en somtijds een weinig droge vis».

Wij vinden door De Rovere van Breugel mede gewag gemaakt van een padi-tiende. *Ten derde - aldus luidt die zinsnede ${ }^{1}$ ) - wordt den Sultan 's jaars de tiende opgebragt van al de rijst, welke in zijn land geteeld wordt, 't welk hij gewoon was aan een gaarder van dit product te verpagten voor een vaste leverantie van 4.000 sanga's padij; dog onder het schrijven deeses heeft hij die belasting verhoogd en gebracht op 18.800 sanga'ss. Het is mij niet duidelijk, wat onder deze tiende van al de rijst, welke in het land geteeld wordt, moet worden verstaan; daaronder zal toch wel niet vallen de «kiras» van ZuidBantam's bergland, en ook is het mij moeilijk te denken aan een padi-djakat, aangezien de inning van deze padi-tiende niet was opgedragen aan de priesters maar verpacht aan een gaarder. Mij lijkt daarom bedoeld hetgeen reeds destijds in Noord-Bantam van de droge rijstvelden op woeste gronden jaarlijks als grondlast verschuldigd zal zijn geweest aan zgn. "pakoekoesoet", eene heffing in natura van den padioogst, en wel zooveel als van het dorpshoofd te verkrijgen viel, welk aandeel inderdaad wel vaak op een tiende schijnt te zijn gesteld geweest. Op verschillende plaatsen blijkt van een dergelijke heffing, zoo o.a. bij het onderzoek naar den staat der Bantamsche peperplanters: "dat op Campong Sumak het volk klaagde, dat in een jaar geen duit betaling voor hun peper hadden ontfangen, dat de Campong thans onder de Ratoe Anom behoord, en hun lieden, buijten peperlanden, nu weder een nieuwe last van 150 sanga's padi 'sjaars was opgelegd».

Hoe in het laatst van den Sultanstijd de agrarische toestanden in Bantam waren, wordt ons medegedeeld in een merkwaardige nota, welke Major Yule aan Raffles uitbracht bij de invoering van diens landelijk stelsel.

*It seems allowed - schreef deze Britsche Resident onder het Engelsch Tusschenbestuur ${ }^{2}$ ) - that all property in the soil rests exclusively in the hands of the Sovereign Power; but

1) B.K.I. 2, I blz. 319.

2) Substance enz. 1814 blz. 123 vlg. Uittreksel in Raffles' History I blz. 156. Holl. vertaling in S. van Deventer, het Landelijk Stelsel I blz. 208. 
in consequence of its having been long customary to confer grants of land upon the different branches of the Royal family, and other chiefs and favourites about Court, a very small portion is now left without some claimant or other.

"The posakas granted to the relations of the Sultan were considered as real property; and sometimes descended to the heirs of the family, and at others were alienated from it by private sale.

- To effect a transfer of this nature, the previous sanction of the Sultan was necessary, after which the parts waited on the High Priest, or Makaboomi, who made the necessary enquiries, and delivered the title-deeds ${ }^{1}$ ) to the purchaser, in which were specified the situation, extent, boundaries, and price of the lands sold. A register of sales was kept by the Priest, the purchaser paying the fees; and it rarely occurred that lands sold in this manner were ever resumed by the Crown, without some adequate compensation being given to the purchaser. Posakas given to Chiefs for services performed were recoverable again at pleasure, and always reverted to the Crown on the demise of the Chief to whom they had been granted $^{2}$ ):

1) Zie Eindrésumé-Java I bijl. D. De eene akte, uitgereikt door den toenmaligen Rijksbestuurder Pangeran Wargadiredja (oom des Sultans, die later op last van Daendels gefusilleerd is) welke akte als zoodanig werd genoemd "piagem saking Boemi" betrof een sawah, groot één djoeng, toebehoorende aan Ratoe Hatidjah en door deze gekocht van een Toebagoes Barosot, die op zijn beurt die sawah door koop had verworven van een Pangeran. Deze sawah wordt genoemd de sawah akoe of kakoean der Ratoe, en blijkt te hebben gegrensd aan een andere sawah welke zij van den Sultan in apanage had (sawah kagoengané Ratoe H. kang ia ikoe patjatoe kang djeng Sultan enz.). De tweede akte is een „piagem saking Hoekoem” (het geestelijk gezag) uitgereikt door den Pěkih, certificeerende dat een desaman uit Paboewaran van zijn vader een stuk sawah ten geschenke had ontvangen, hetwelk deze oorspronkelijk van een Toebagoes op wettelijk gestaafde wijze had gekocht.

2) De grooten, schreef De Rovere van Breugel (t.a.p. blz. 164) zijn meest arm, haar voornaamste bezittingen bestaan in eenige diamanten, goud en zilver. Die pepertuinen hebben of rijstvelden, hebben nogal een bestaan, de vruchten des lands aan hunne onderhoorigen met geringe koopmanschappen betalende en van de winst op dezelve haar staat onderhoudende. Bedieningen, als die van Sjahbandar en Rijksbestuurder, die eenige vaste winst geven, van deze is bij overlijden de Koning gemeenlijk erfgenaam. Dus zijn er geene, die hunne kinderen veel rijkdom zullen nalaten. De meesten zijn wel tevreden, als zij een aangename en gemakkelijke woning, een speelvaartuijg en rijpaard en eenige mooije vrouwen tot hun gerief hobben. Al 
in all other respects, the same privileges were annexed to them as to the former. Previous to the year 1810, the posaka lands are said to have paid no revenue to the Sultan, either in money or in kind, the proprietors being only bound to attend the Sultan with their dependants in all occasions, whether called for the purposes of war, for the protection of property, or for the construction of public roads. At the above period, the Dutch assumed the entire management of the lower countries, and it was ordered that one-fifth of the produce of paddy and cotton should be collected, on account of Government, from all lands whatever: the same as had formerly been collected by the Sultan from the crown lands only. ${ }^{1}$ ) All other crops, including sugar-cane, sweet potatoes, cocoa-nut and other fruittrees, seree-leaves, etc. etc., are said to have paid no revenue, either to the Sultan or to the holders of the posakas, having been left at the disposal of the cultivators: - it is allowed, however, that the cultivators were always in the habit of making presents of every article in its season. The holders of posaka lands were very seldom the occupants: they generally remained about Court, and on the approach of the paddy. harvest, deputed agents to collect their share of the crop. But what proportion their share would bear to the whole produce, does not seem to be well defined: - it is by one stated at

het overige laten zij zig welgevallen. Huc nsque et non plus ultra". - Daendels schafte met het abdischap tevens af dit Sultanserfrecht, doch stond toen den Sultan nog toe om den boedel van den gefusilleerden Rijksbestierder te naasten; zie Plakaatb. XV blz. 357 op 24 Nov. 1808 en op blz. 364 art. 19 van de Instructie voor den Sultan van Bantam.

1) Zie aldus ook de Resident de Bruyn in diens verslag over Bantam in 1817 bij M. L. van Deventer, Het Nederl. Gezag over Java sedert 1811 blz. 145. Die sultanatsbelasting speciaal ten bedrage van $\frac{1}{5}$ van de katoen en de padi gelijkt echter bijzonder op de door Daendels bij zijn Reglement van 19 Juni 1808 voor Cheribon ingevoerde rijstbelasting en zijn ten opzichte der katoenteelt aanbevolen leverantie van Javaansche kapas (in stede van katoenen garens), waartoe de prefecten werden aangeschreven om den aanplant daarvan "te extendeeren over $\frac{1}{5}$ gedeelte der in UEd. district bevindende rijstvelden" (Plakaatb. XIV blz. 706 en 822). Bantam werd 22 Nov. 1808 verklaard tot domein van den Lande en gesteld wel is waar onder een Sultan, maar met naast dezen een prefect, naar wiens bevelen hij zich zou hebben te gedragen, ook t.a.v. lasten en contributiën op zijne onderdanen, terwijl het Gouvernement uit Bantam alleen voordeelen zou trekken uit den aanplant van koffie en peper, en het lijkt mij, dat bij het inwendig bestuur over Bantam met betrekking tot de grondlasten de Cheribonsche regeling tot leidraad is genomen. 
a fifth ${ }^{1}$ ), by another at a tenth, and by some (which I suspect to be nearest the truth) at as much as the cultivator could afford to pay, the agents of the proprietors being the judges of the quantity.

¿The proprietors of posakas have also a claim to the services of the cultivators. A certain number of them are always in attendance at the houses of their Chiefs, and on journies are employed in carrying their persons and baggage.

-The proprietors of posakas do not let their lands for specific periods; the cultivators are liable to be turned out at pleasure, and the people ejected have no claims to compensation for improvements made while in their possession, such as watercourses, or plantations of fruit-trees made by themselves or their parents. On the other hand, the cultivators may throw up their lands whenever they think fit to do so. Lands not posaka used to pay the same proportion of produce to the Sultan as the others did to the proprietors; but the cultivators of the royal dominions laboured under greater disadvantages than the others. Every Chief or favourite about Court had authority to employ them in the most menial offices; and Chiefs possessing posakas, often spared their own people and employed the others.

-The Sultan always had a right to enforce the culture of any article which he thought proper to direct, and in such cases, a price was paid upon the produce, which was generally very inadequate to the expenses. Pepper, as above-mentioned, was paid for, at the rate of seven Spanish Dollars per bahur: the natives were accordingly averse to the culture of this article, but far more so, to the introduction of coffee plantations». ${ }^{2}$ )

Yule's voorstelling heeft bestrijding gevonden, en een geargumenteerde, doch alvorens ik dit dit vertoog, hetwelk ongeveer zestig jaar later door de Controleurs B. B. Spaan en Valck werd geschreven ${ }^{3}$ ), behandel, worde het verloop van het domeininstituut in Bantam geschetst.

Toen het Engelsch Tusschenbestuur zich aan de zaken van

1) $\mathrm{Bij}$ den overgang der Benedenlanden op het Hollandsch Bewind in 1810 was hier door Daendels ingevoerd de belasting van het één vijfde der padi (in product) en van de kapas (in geld).

2) Door Daendels in 1808 (Plakaatb. XV, blz. 363, art. 12).

3) Eindrésumé-grondenrecht Java dl. II bijl. A, 
Bantam zette, vond het Zuid-Bantam in de handen van een Pangeran Ahmad, half rebel half piraat, den Sultan in diens macht, het onder rechtstreeksch Hollandsch bewind gebracht noorder-gebied in een staat van anarchie alsmede een gedeelte van de Sultans-familie en van de voormalige hofhouding in een toestand van "utmost want and misery». Deels hadden deze poesaka-houders wegens willekeurige handelingen der drie laatste Sultans - de een was al zwakker en meer speelbal zijner omgeving geweest dan de ander - - deels wegens opheffing van het Sultanaat in de Benedenlanden hun bediening en dienovereenkomstig hun sawahs verloren. En alle andere geapanageerden hadden hun padi-inkomsten gevoelig zien verminderen, waar Daendels had gelast dat van de heffing van het $\frac{1}{5}$ geen landen uitgezonderd zouden zijn.

Voor deze geprivilegieerden was dientengevolge de toestand zóó hachelijk geworden, dat Yule het Gouvernement om voorlichting vroeg. Het antwoord luidde, dat het verstandig mocht heeten om dergelijke aanzienlijken tegemoet te komen, waartoe de invoering van de landrente gelegenheid zou verschaffen, en inderdaad vinden wij daarbij onderscheid gemaakt ${ }^{1}$ ) tusschen government- en poosakah-land, en laatstbedoeld bezit belast met slechts de helft van den aanslag der gouvernementsgronden. Bantam was met het oog op de invoering van het nieuwe landelijk stelsel verdeeld in twintig districten, waarover het beheer was toevertrouwd aan als 'farmers, betitelde hoofden, en het is met het oog op de rechten en plichten der bevolking nuttig te letten op de volgende bepalingen in de landrentepiagem:

-It being the intention of Government, to extend as far as possible to the lower classes the benefit of this arangement, the Renters of districts shall bind themselves either to cultivate the ground at their own expenses, or to sublet them at a moderate and fixed rent to the cultivators themselves, and on no account to other chiefs», m.a.w. de kleine man had heel zwak bewerkingsrecht; en:

-The Renter binds himself to maintain the public roads, bridges and tancies in his district, in a proper state of repair; and when Government requires the services of the inhabitants

1) Zie de stukken bij M. L. van Deventer, het Ned. Gezag over Java sedert $1811 \mathrm{I}$, blz. $15 / 17$. 
for any other purpose, they are to be forthcoming, and to be paid by Government by a reasonable rate for their labours, * m.a.w.: voor de openbare wegen, bruggen en rusthuizen had de bevolking in onbetaalden heerendienst te zorgen; werd zij van Gouvernementswege voor andere doeleinden gerequireerd, dan zou zij daarvoor betaling genieten; alle bijzondere diensten, de zgn. «feudal services» voor anderen dan het Gouvernement, werden afgeschaft, dus ook die voor de Inlandsche hoofden en grooten. Het is een misvatting, dat Raffles de heerendiensten zou hebben opgeheven; afgeschaft werden destijds de heerendiensten voor de huishouding der hoofden, voor cultuur- en handelsdoeleinden zooals in den tijd der Compagnie, maar geenszins de diensten ten openbaren nutte; deze bleven in stand, werden echter, evenals in het Bataviasche in den natijd van de V.O.I.C., onderscheiden in betaalde diensten, o.a. voor het vervoer van Gouvernementsreizigers en -goederen, en onbetaalde, voor werken ten algemeenen nutte ${ }^{1}$ ).

De landrente-administratie is onder het Engelsch Tusschenbestuur een chaos geworden, waarmede de voormalige apanagehouders ongetwijfeld hun voordeel hebben gedaan, en vermoedelijk zal dit wel mede het geval zijn geweest in den tijd na de herstelling van ons gezag, want de landrente-regeling van 1819 kende nog geen opmeting en classificatie der gronden, en liet de bepaling van het bedrag van den aanslag over aan een overleg met de hoofden en oudsten van elke desa, waarbij uiteraard de poort wijd openstond voor allerlei schikkingen, die tijdelijk trouwens haast onmisbaar waren bij een regeling, welke tusschen poesaka - en niet poesaka - bezit niet meer onderscheidde. Opgelost was de quaestie van dit bezit geenszins, het Europeesch Bestuur bleef er echter blijkbaar buiten tot in 1820 de Regent

1) Vgl. Raffles' Minute $§ 34$; in de Hollandsehe vertaling bij S. van Deventer, het Landelijk Stelsel enz. I blz. 80 is een fout ingeslopen, die storend is: in den derden regel van $\$ 34$ leze men i. p. v. mitsdien- bovendien (Eng. tekst: also). - In het hooger aangehaald, bij M. L. van Deventer afgedrukt huurcontract leest men o. m. den term tancies, waarbij v. D. tusschen haakjes oppert "tanks"; waarschijnlijk is bedoeld tangsi, barak, kazerne, en, zooals tot voor kort in Indramajoe nog, in de beteekenis van pasanggrahan, rusthuis, immers in Raffles' tijd langs Daendels' Postweg in stand gehouden. Raffles' heerendienst-politiek heeft onder den invloed gestaan van hetgeen dienaangaande door de Ind. Regeering der V.O.I.C. te beginnen met de Publicatie van 31 Dec. 1778 in het Bataviasohe was verordend. 
van het Noorderregentschap Pangeran Soera Manggala, familielid en exvoogd van den verbannen Sultan Alioeddin II kwam te overlijden, en in diens nalatenschap werden bevonden "eene meenigte erfelijke sawahvelden, vischvijvers en dergelijke, bekend onder den naam bosacca ladèn, omtrent dewelke - schreef de Resident Tobias - indertijd door middel van de inspectie over de geheele residentie, een billijk voorstel aan Uwe Excellentie zal dienen te worden aangeboden». "In de bij dit rapport gevoegde staten - teekenden Spaan en Valck aan - vindt men gronden, tot verschillende desa's behoorende, afgestaan aan hofmeesters, krissenmakers en gamelanspelers van den Sultan», en, hoe diep de agrarische instellingen tijdens het Sultansbestuur in het volksbewustzijn waren gegrift, blijkt wel hieruit dat men in 1870 nog wist van sawah kasoeltanan, kadalěman, kawargaän, kapěkihan, kamesdjidan en kadjaroan.

De Resident Tobias kreeg op zijn voorstel de beschikking over eenige opzieners voor de landelijke inkomsten, en door de aanstelling van regenten en andere hoofden, alsmede door de plaatsing van Europeesche ambtenaren te Lebak en te Tjilangkahan werd Bantam onttrokken aan den aan regeeringsloosheid grenzenden staat, waarin het zich zoolang had bevonden. Er werd gereisd, onderzocht, geleid en in 1827 vindt men een rapport, uitgebracht door den in die tijden veelvuldig voor dgl. commissies aangewezen Resident Van Sevenhoven (later Raad van N.-I.) over den staat van het Inlandsch en huishoudelijk bestuur in de residentie Bantam, waarbij aan het agrarische gedeelte een ruime plaats werd gegeven ${ }^{\mathbf{1}}$ ).

$\mathrm{Na}$ gewezen te hebben op de rampzalige gevolgen van onverstandig en onvoorzichtig sultansbestuur, wanorde en regeeringloosheid, waardoor de oude instellingen verwaarloosd waren en de dorpshuishouding uiteen was gerukt, legde Van Sevenhoven nadruk op het noodzakelijkheid om het dorpswezen te organiseeren : *in een woord - schreef hij - het is het dorp waarvan wij voor ons bestaan in Indië alles moeten verwachten; het dorpsbestuur is het palladium, waarop ons bestaan rust... De dorpen (waren) zeer slecht en ligt te zaam gesteld; evenals in Cheribon met goed gevolg het desa-wezen was ver-

1) Gedeeltelijk opgenomen in het hiervoor aangehaald Rapport van Spaan en Valck. 
beterd, zoo dienden in Bantam de gehuchten verzameld te worden, grenzen vastgesteld, het vrij kiesrecht ingevoerd en in de dorpen de oude geslachten waaruit de orang toewa zouden zijn te kiezen, in eere gehouden te worden ${ }^{1}$ ). Agrarischrechtelijk onderscheidde Van Sevenhoven tusschen $1^{\circ}$ de "sawa negri behoorende aan de geheele desa of de inwoneren gezamenlijk; $2^{\circ}$ de sawa poesaka der Sultans, hunne familieleden en geapanageerden; $3^{\circ}$ die velden, waarop de eerste ontginners, en dus enkel de personen recht hebben, en die bekend zijn onder den naam van sawah jasa; het woord jasa be-

1) Ten opzichte van de bestuursorganisatie deelde Van Sevenhoven mede dat "onder den Demang (divisiehoofd) stonden acht districtshoofden", die schreef hij - „alhier den naam hebben van bèk (wijkmeester) en vroeger genaamd wierden djenang". Deze verbasterd-Hollandsche benaming bèk (evenals die van mandor voor dorpshoofd blijkbaar uit de Bataviasche Ommelanden naar Bantam overgebracht) schijnt zelfs in Lebak, het primitieve Zuid-Bantam, in zwang te zijn geweest. Wij lezen ten minste bij Van Baak (t.a.p. blz. 171), dat nà 1820 die titel niet meer werd gegeven aan de stamhoofden, zooals Van Bak de volkshoofden in Lebak noemde (wijl destijds de dorpsbevolking aldaar zich nog min of meer verwant zoowel onderling als met het dorpshoofd gevoelde).

Ditzelfde Bestuurshoofd deelde mede, dat omstreeks dien tijd door den Resident Tobias aan de districtshoofden de titel demang was geschonken, een titel welke in de Javaansche Vorstenlanden en oudtijds ook daar buiten, waar de Javaansche adat in zwang was, Cheribon en zelfs Bantam ingesloten, gebezigd werd voor een kleinen prijaji, die als loerah dèsa eenige bekels of dorpshoofden onder zich had, en op zijn beurt stond onder den districtstoemenggoeng, tot wiens nabestaanden hij over het algemeen behoorde; hij woonde gewoonlijk in de hoofdnegerij, was bekleed met politiegezag, ontving van de bekels de pachten en zorgde voor de heerendiensten; hij was in een woord, het kleine Javaansche bestuurshoofd, wiens ambt stond tusschen dat van districtstoemenggoeng en het dorpsheofd [rgl. Raffles bij S. van Deventer het Landelijk Stelsel I blz. 70 al. 8]. Bij Daendels [S. van Deventer, t. a.p. I blz. 20 noot] leest men: „dessa is een dorp of buart, bestuurd door een demang, groot of klein mantrie of een loerah, naar mate van derzelver uitgestrektheid." Soms was het demangsressort z. v. a. een district of onderdistrict; in het Bataviasche heetten de latere districtshoofden ook demang. - Van Sevenhoven's djenang is wel het Javaansche djĕněng in de beteekenis van stijl (bijv. van een beschot), een ander woord voor djaro, zooals tegenwoordig het desahoofd in Bantam (figuurlijk) wordt genoemd. - In het begin der $19^{\circ}$ eeuw, schreef Van Baak (t.a.p.) in zijn nota van 1867, werden de deelen van het Bantamsche rijk bestuurd door poenggawa's, zooveel als regenten (inderdaad stond in den tijd van De Rovere van Breugel een „erfpangeran" over Tjaringin als gouverneur van dit landschap), terwijl rechtstreeks over het volk hoofden gingen, die meestal den titel van ngabèhi en soms dien van loerah voerden, en die, merkte van Baak op, evenals bijv. op Bali in Boelèlèng nslechts 
teekent, het recht op het voortbrengsel des gronds door arbeid verkregen., Gemoedelijk en rechtschapen ambtenaar, gaarne met Inlandsche hoofden sprekende en zijne berichtgevers over het algemeen goed kiezende, zoo had Van Sevenhoven nochtans niet altijd vasten grond onder de voeten. *Hoe deze drie soorten van regt verkregen zijn, vervolgde hij, is het mij niet mogelijk geweest hierin naar wensch te slagen.» Hem was echter meegedeeld "dat de Sultan of heer van de landen als de wettige en eenige hoogere bezitter werd beschouwd van den grond van het geheele rijk, dat hij gebiedt, dat daar waar hij gelast had, dat men gronden tot sawahvelden zoude aanleggen, en daartoe door het doen graven van waterleidingen, het in gebruik geven van buffels, het voorschieten van rijst of geld, veel had bijgedragen, deze velden waren ge-

onderhoorigen en geen bepaald begrensde onderhoorigheid hadden", ten bewijze waarvan verschillende feiten door hem werden aangehaald. Sommigen dezer ngabèhi's hadden „uitgestrekte landen en talrijke gehuchten ... erfelijk .. onder zich." Onder ons gezag werden deze ngabèhi's mandor en later djaro genoemd. De Ass. Resid. Du Bois, later in de Lampongs, was \pm 1820 in Bantam belast met het maken van grensscheidingen tusschen de districten, en onder den Resident Tobias werd in het belang van politie en landrenteinning het aantal "mandor"-schappen zeer vermeerderd. In 1846 gelastte de Resident Buyn dat geen dorpshoofd meer dan 25 gezinnen onder zich mocht hebben, hetgeen talrijke desagebiedssplitsingen tengevolge had. Dergelijke splitsingen waren intusschen niets vreemds, waar wij o.a. met betrekking tot den Sultanstijd (Eindr. II blz. 3 noot a) meêgedeeld vinden, dat in één desa vier hoofden, zaakgelastigden van geäpanageerden, woonden, die gingen over het aandeel hunner meesters, onder wie de gronden der desa verdeeld waren. Men ziet derhalve, dat in Bantam, evenals in de Preanger, de tegenwoordige desa met haar afgerond politioneel gebied, heel vaak een nieuwe schepping is. Hetgeen niet wil zeggen, dat in Bantam oudtijds geen desa's bestaan hebben; slechts zal men steeds hebben te letten op locale en historische omstandigheden in het primitieve zuiden en het onder Javaansch vorstenbestuur sterk gecentraliseerde noorden. Zal men bijv., gelijk het voorbeeld van Cheribon leert, juist in dit noorden de desa met haar raadhuis, gemeentebestuur en gemeenschap van sikeps mogen zoeken, daarnaast zal men moeten rekening houden met het onder Javaansch vorstenbestuur gelijk in Balineesche rijkjes van ouds geldend begrip: de vrije man heeft het recht om bij onrechtvaardige behandeling zich door een ander of hooger hoofd te laten aannemen, waarbij dan de bouwgrond den persoon van dien ondernoorige volgt.

Naast de bevolkingstoeneming zijn evenbedoeld bestuursbeginsel en de hebbelijkheid om de bevolking van éen desa onder verschillende poenggawa's of apanagehouders te verdeelen factoren geweest, welke de desa-instelling hebben gemaakt tot wat deze ten slotte geworden is. 
houden voor sawah negri; dat hij als zoodanig ook verkreeg velden, die verlaten waren, en velden van degenen, die misdaden hadden gepleegd., De sawah jasa waren door de bevolking zelf aangelegd en daardoor hun wettig eigendom; hiervan vond verkoop plaats met vergunning van het betrokken desa-hoofd, die eerst de ingezetenen vroeg of dezen het veld wilden koopen, en daarna de anderen, - een gewoonte waaraan men zich evenwel niet steeds hield. De sawah negri behoorden toe aan de ingezetenen van het dorp gezamenlijk en konden niet vervreemd worden; alle die velden waren meest in gelijke groote aandeelen verdeeld (zoo bijv. in Pontang), en zij gingen over op de oudste zonen der afstammelingen van degenen die deze velden hadden ontgonnen. De tjatjah-instelling had in Bantam bestaan; deze tjatjahs waren belasting- en dienstplichtig geweest khetgeen men ook noemde koerowang wanneer de belasting

In 1787 schreef De Rovere van Breugel over het bestuur ten platten lande onder het sultanaat: „in de Bantamse dorpen zijn de huizen alle zonder order onder elkanderen gebouwd; elk kiest zig een plaats tot het maken van zijn woning, waar hij het goed vindt. In de meeste dorpen is een open, langwerpig en vierkant gebouw van bamboesen en op eenige voeten van de grond gebouwd, hetwelk hun raadhuijs is, en alwaar de orders van hunnen vorst worden afgekondigd, dienende hetselve tevens tot een vergaderzaal van hunne hoofden." Dit dorpsraadhuis is sprekend het beeld van de tegenwoordige bale-desa in Cherıbon en de sěsat in de Lampongsche districten, en mag daarom in Bantam, evenals in laatstgenoemd gewest, dat immers Bantamsch territoir is geweest, beschouwd worden als tevens te hebben gediend tot raadzaal ter berechting van kleine geschillen. Met betrekking tot de Vorstenlanden, en het de instellingen daarvan handhavend deel van Java schreef Raffles (History I blz. 310): „petty tribunals, under like names (n.l. van panghulu en djaksa), are even established under the jurisdiction of a Demang, or chief of a subdivision, and sometimes of a Bàkol or head of a village; but in these the authority of the Panghulu and Jaksa extend no further than to take down evidence to be transmitted to some higher authority, to settle petty disputes, and perform the ordinary ceremonies of religion, inseparable among the Javans, as well as all other Mahommedans, from the administation of justice." In de Lampongs hadden volgens Du Bois (T. N. I. 1852 I blz. 255) de poengyawa's en lagere hoofden het recht om geldboeten op te leggen tot een overeenkomstig hun rang bepaald maximum: een kapala marga bijv. die in het bezit was van een door den Sultan van Bantam afgegeven piagem zoomede van een pepadon [deze adat-term voor een staatsiezetel in de sesat wijst vermuedelijk óók op de marga- en dorpsrechtspraak want padoe $=$ geschil] mocht straffen met eene geldboete tot hoogstens $2 \times 15$ realen, enz. In Palembang, dat ook de Javaansche adat volgde, zij het uit lateren tijd, varieërde dit beboetingsrecht der margahoofden tusschen 12 en 36 realen. 
in geld werd opgebracht» (wang koerěnan? = huisgezinsgeld).

In Van Sevenhoven's rapport vindt men de feiten uiteengezet benevens eenige gemoedelijke beschouwingen, echter geen historischen terugblik, en hiertoe was toch wel aanleiding. Tusschen 1827, het jaar van Van Sevenhoven's rapport, en 1810, toen het Sultansbestuur over Bantam's Noordergebied ophield, lag de invoering van een nieuwe bestuursinrichting, waardoor tal van voormalige sultans-geapanageerden hun ambt of dienst verloren, doch - en dat gold vooral voor de laagste rangen hun ambtelijke sawah niet konden missen, wilden zij niet verhongeren; vervolgens Raffles' oplegging van het landelijk stelsel, waarbij eenerzijds ten opzichte van verarmde sultansafstammelingen de landrente der poesaka-sawahs tot de helft werd teruggebracht, anderzijds aandacht werd gewijd aan de bewerkingsrechten der opgezeten desalieden; tenslotte het zeer belangrijk Besluit van Kommissarissen-Generaal van 4 Januari 1819 no. 1 (Ind. St. no. 5), hetwelk $1^{\circ}$ belangrijk heeft bijgedragen tot verlaging van den in Bantam veel te zwaren belastingdruk; $2^{\circ}$ een desa'sgewijzen landrente-aanslag voorschreef, zoolang de landen niet behoorlijk zouden zijn gemeten (hetgeen eerst in onzen tijd heeft plaats gevonden); en $3^{\circ}$ den residenten ten plicht stelde "dat bij deze verdeeling de wettige bezitters, zooals daar zijn: de eerste ontginners der gronden of derzelver erf"genamen en anderen, die volgens de herkomsten der Inlandsche < bevolking of uit eenige anderen hoofde, als wettige bezitters "beschouwd moeten worden, in hunne regten niet worden ver"kort.» In verband met wettelijke bepalingen als deze was er toch wel aanleiding om te vermoeden, dat bouwgronden, welker ontginners nog in leven waren, eerder en algemeener als erfelijk individueel bezit zouden worden aangemerkt, dan die, welke reeds geslachten lang tot de sawah negara van het voormalig rijk van Bantam hadden behoord. Achttien jaar later in een rapport over den Tjikandi-opstand van 1845 schreef de assistent Resident Buyn $^{1}$ ) dat het erfelijk individueel bezit van de gronden der landbouwers niet berustte op de landsinstellingen, maar alleen een gevolg was van usurpatie, welke in den Sultanstijd onmogelijk zou zijn geweest doch daarna tot stand kon komen, doordien de Regeering, toen eenmaal het gezag over

1) Tijdschr. Ned. Ind. 1859, I, blz. 165 . 
Bantam in haar handen was overgegaan, zich in het geheel niet meer met de wijze, waarop het landbezit door de inlanders werd uitgeoefend, inliet. Meer overeenkomstig de bedoeling der Regeering zou geweest zijn, als deze Resident hier op agrarisch gebied haar streven naar bescherming van den kleinen man recht had doen wedervaren in stede van te spreken van onverschilligheid, doch zijn opmerking is niet onjuist te achten, want ongetwijfeld heeft de Regeering door haar politiek van overlaten eene ontwikkeling van het jasa-recht bevorderd, welke onder het Sultanaat ondenkbaar zou zijn geweest.

De tijd ook is het geweest die, gelijk zoo menige aangelegenheid, de Bantamsche quaestie der Sultansgronden en apanages (poesaka ladèn) tot oplossing heeft gebracht. Er was geopperd om deze "poesaka"-gronden voor rekening van den Lande over te nemen, om ze daarna onder den kleinen man te verdeelen, doch, naar de Resident Melverda in 1828 berichtte, "uit hoofde der enorme som, welke voor vergoeding zou moeten worden besteed", werd besloten "dat punt te laten zoo het was». Het poesaka-bezit bleef in de handen der houders; vele voorname familiën woonden niet meer als vroeger ter hoofdplaats Bantam, het hoofd van het geslacht had niet meer alle macht over het oude familiebezit, ieder beschouwde zich als eigenaar van het stuk grond, waarvan hij de inkomsten trok en een deel der poesaka-gronden geraakte, zooals in het cultuurverslag van 1832 voorspeld werd, door verkoop in de handen van den kleinen man.

In de westelijke helft van het regentschap Sérang schijnt het instituut der sawah negara ${ }^{1}$ ) nog geruimen tijd min of meer te hebben bestaan; zij werden beschouwd als verkeerend in een anderen rechtstoestand dan de krachtens ontginning of door koop verworven milik-sawahs; de aandeelen waren er nog meest van gelijke grootte; het bewerkingsrecht ging, gelijk vroeger, bij versterf over op den oudsten zoon, en de grond behoorde bij niet-nakoming van de landrente- of heerendienst-verplichtingen alsmede bij verhuizing uit de desa ter beschikking der

1) In het Eindrésumé II blz. 5 onder $\$ 6$ leest men: „De in heerendienst aungelegde sawahs, thans bekend onder den algemeenen naam van sawah negara, worden aangetroffen in ongeveer 400 desa's, allen gelegen in de nabijheid van den zetel van het oude Sultansbewind en voorts in één desa onder Tjaringin". 
dorpsgemeenschap te komen. Maar sedert is ook hierin verandering gekomen; in een nota van 1915 werd de toestand als volgt beschreven: ${ }^{1}$ )

"Volgens bekomen inlichtingen, heeft men thans, zoowel in de westelijke als in de oostelijke helft van het regentschap Sérang slechts sawah milik (erf. ind. bezit) en sawah wakaf voor het onderhoud van mesigits, van de heilige graven van de Sultans en van andere als heilig beschouwde personen. Sawah negara heeft men sinds 1886 niet meer, ook niet in de omgeving van oud-Banten. Dat de sawahs tegenwoordig milik zijn, blijkt wel uit het volgende: In de landrente-boeken komen ze als "sawah milik» voor. De bezitter mag de sawah verkoopen. Het bezitsrecht gaat bij versterf over op de erfgenamen, alleen landrente wordt van den oogst geheven. Vele bezitters wonen te Pandeglang, Rangkasbitoeng en andere plaatsen buiten de desa in het regentschap Sérang.

«De grondbezitters, die heerendienstplichtig zijn, heeten «djælěma koewat»; de naam "sikęp» is nu niet meer bekend, vroeger wel, toen er nog sawah negara bestond.

"Zooals boven reeds is gezegd, bestaan sedert 1886 de sawah negara of kasoeltanan niet meer. In dat jaar vond de conversie - wanneer ik het zoo noemen mag - van sawah negera in sawah milik plaats. Kennelijk verlaten kasoeltanan-gronden werden na 1896 ter her-ontginning afgestaan aan de bevolking en die, welke niet afgegeven werden, werden vrij staatsdomein heeten nu tanah "pasrahan». Deze conversie staat bekend onder den naam van "ngitrikeun " en de "kitri" is de sawah zelf. Sawah "kitri» en sawah "milik» verkeeren geheel en al in denzelfden rechtstoestand. Eenig verschil bestaat er niet, behalve dan in naam.

"Af en toe melden zich personen als afstammelingen van de Sultans bij het Bestuur aan, die beweren nog het volle recht te hebben op een of ander stukje sawah, gewoonlijk op de door de bevolking opnieuw ontgonnen sawahs. De zaak wordt gewoonlijk naar den rechter verwezen en de beslissing is steeds: ontzegging van den eisch, aangezien de tegenwoordige bezitters

1) Door Raden Hasan Somadipradja, die terzake was ingelicht door den Regent en een gewezen Wadana, afstammeling van een der Sultans alsmede door den schrijver van den Assistent-Wadana van Kasĕmĕn en een paar desalieden. 
in het bezit zijn van een ontginningsvergunning, en de gronden vóór de ontginning kennelijk verlaten waren.

"In de omgeving van het graf van Maolana Joesoef - volgens de overlevering den sultan, die veel had gedaan voor de uitbreiding van den sawahbouw in de omgeving van Banten te Pakalangan, heeft een van mijn zegslieden mij een complex sawah van een paar honderd bouws "sawah milik» aangewezen, dat vroeger "sawah negara» was.

« Na de conversie brachten de grondbezitters hier en daar nog wel "pakoekoesoet» op aan de desahoofden, soms ook wel aan de wedana's en assistent-wedana's, hoewel het vanaf 1886 streng verboden was. $\mathrm{Nu}$ komt het niet meer voor.

"Pakoekoesoet» was een oogstheffing ten bedrage van $\frac{1}{5}$ van den oogst.

-Wat de wakafgronden betreft, bijna alle heilige graven en de Masigit Agoeng van Oud-Banten hebben hun wakafgronden. Zoo heeft het graf van Maolana Abdoel Moefakir te Kenari nabij Kèdoengtjindé, de standplaats van den Assistent-Wedana van Kasěm̌n, ruim 100 bouws sawah en droge gronden; dat van Maolana Joesoef te Pakalangan \pm 50 bouws en dat van Maolana Hasanoedin en de Masigit Agoeng ruim 150 bouw. De wakafgrenden hebben neiging zich uit te breiden, aangezien rijke geloovigen nog altijd gronden als wakaf aan die graven en de mesigit afstaan. Ze staan onder het beheer van "pakoentjens», gewoonlijk afstammelingen van de Sultans, en die van het graf van Hasanoedin en de Masigit Agoeng onder beheer van den over die masigit door den Regent van Sérang aangestelden Panghoeloe.»

De omzetting van dit oorspronkelijk recht op het gebruik van een aandeel in de sawah negara of kasoeltanan, laatste overblijfsel van het voormalig met speciale diensten bezwaard dan wel ten voordeele van vrome stichtingen aangewezen sultansdomein, in het erfelijk individueel bezitsrecht der onder ons Bestuur geoccupeerde gronden is het laatste stadium van een vervormingsproces dat het grondenrecht in Bantam heeft doorgemaakt na de inlijving bij het rechtstreeks bestuurd gebied. Daendels' domeinverklaring maakte in beginsel een eind aan het sultanaats-eigendomsrecht op het complex der sawah-akoe of vervreemdbare poesaka's, welke oorspronkelijk het werkelijk eigendom waren van leden der sultansfamilie 1)l. 81. 
en oudtijds behoudens mededeeling aan het Sultansgezag op anderen mochten overgaan. De opheffing van het Sultanaat deed veel apanage (petjaton- of poesaka ladèn-) -bezit openkomen wegens het vervallen van sultanaatswaardigheden of -bedieningen. De uitbreiding van de oogstbelasting, de latere landrente, tot alle sawah-bezit benadeelde de voormalige geprivilegieerde personen, maar toen de landrente verlaagd werd tot een peil, belangrijk beneden het oude bedrag, had die voor den kleinen man gunstige ommekeer ten gevolge dat op alle niet-apanage-bezit het gebruiksrecht van den desaman sterk in waarde toenam. Hield, tijdens het sultanaat, het jasa-begrip niet meer in dan dat de sawah tijdens den traditioneelen ontginningstermijn vrij was van pacht, en daarna, wanneer de ontginning was ingelijfd bij het domein, dat de ontginner een recht van voorkeur genoot bij de bewerking der dienstplichtige sawah in dier voege dat, zoo lang hij de op den grond rustende verplichtingen nakwam, hij in het genot daarvan werd bestendigd, - onder het Gouvernementsgezag werd vervreemding van het vervolledigd jasa-recht toegelaten, en ten slotte niet meer tusschen jasa en milik onderscheiden.

Dit proces is van langen duur geweest. Omstreeks 1830 was het jasa-recht al zoover gevorderd, dat het Gouvernement wel is waar zonder bezwaar de aanplanting van suikerriet op de immers nog domein zijnde bevolkings-sawahs kon invoeren, maar het Binnenlandsch Bestuur moest het plan opgeven om eigenmachtig over de sawahs te beschikken. Toen immers in 1844 de Resident Buijn het plan opperde om de verbrokkeling der riettuinen over tal van verspreide plekjes ${ }^{1}$ ) op te heffen en in het belang van het Cultuurstelsel het communaal bezit à l'instar van Midden-Java in te voeren, rieden de beide Bantamsche Regenten dit voornemen met klem af: het gemeen bezit, zeide de eene regent, kon in Bantam alléén slagen «ingeval het Gouvernement bij elk grondstuk een soldaat plaatste», en de ander: "als men de bezitters schadeloos stelde (ganti oesaha)». Aan den anderen kant was van het oude begrip: de grond is van den Vorst, genoeg overgebleven dan dat de bevolking zich het moeilijk zou hebben gemaakt over een ander bevel van datzelfde bestuurshoofd, n.l. om in het belang eener betere

1) Rapport Adj. Insp. Ament 1834 bij S. van Deventer, Het landelijk stelsel II blz. 697 . 
politie in de desa, het tot dien toe gebruikelijk verspreid wonen tusschen haar sawahs en tuinen - elk op eigen gedoe - op te geven, en zich bijeen te groepeeren in niet te kleine nederzettingen, waartoe natuurlijk wel eens over den grond van anderen moest worden beschikt ${ }^{1}$ ). Slechts in één desa is verklaard, dat schadevergoeding voor dien afstand zou zijn genoten; in andere dorpen heette het wel bij het grondonderzoek van 1867, dat de grond nog behoorde aan de oorspronkelijke bezitters, maar de regel was - en in het licht van die sultanaatstoestanden niet onverklaarbaar - dat de ingebruikneming van den grond voor de nieuwe woonerven plaats had gevonden op last en zonder eenige sciiadevergoeding. Dat destijds de Bantammer hierin zou hebben gezien een "verstoring van rechten", zooals in Fokkens' Eindresumé der persoonlijke diensten in 1889 wordt gemeend ${ }^{2}$ ), komt mij eene redeneering "après coup» voor. Nog zóó sterk toch was in 1867 nog de herinnering aan het vorstelijk eigendomsrecht op den grond dat in de desa Poeloe Merak hadji Sawi verklaarde: "men kent zich de jasa toe, dat is hetgeen de grond door eigen werkzaamheid is geworden, maar de grond behoort aan het Gouvernement; daarom moet ook van de opbrengst belasting worden betaald.»

Teekenend voor den geest van het in 1868-71 gehouden Bestuursonderzoek naar de rechten van den Inlander op den grond is, dat alstoen aan evenaangehaalde mededeeling werd toegevoegd:

"In de desa Poeloe Merak werd, na de eerste hierboven aangehaalde verklaring door een gewezen desageestelijke gezegd, dat de woeste grond hak oellah is, en dat die door de bewerking hakoeladam wordt. Op de vraag, hoe dit rijmde met de vroegere verklaring, ontstond er een debat, waarvan de slotsom was, dat de meesten erkenden, dat zij den grond beschouwden als hun eigen, maar dat zij het niet durfden te zeggen uit vrees voor het Gouvernement», terwijl in een noot werd aangeteekend: "in het verbaal wordt er bijgevoegd: men dient in aanmerking te nemen dat door het bestuur in vroeger tijd voor verschillende doeleinden, als voor het bouwen van twee redoutes, een pasangrahan en de woning van een mantri, zoomede ten behoeve der Gouvernementscultures, willekeurig over gronden aldaar is be-

1) Eindrésumé-Java I blz. 174/6.

2) T. a. p. II blz. 21 . 
schikt.» Beschikt - zeer zeker; maar willekeurig? d.w.z. ten tijde van die beschikking?

Niet geheel ten onrechte had in $1857 \mathrm{Mr}$. H. D. Levyssohn Norman naar aanleiding van het denkbeeld betreffende zulk een onderzoek naar het Javaansch grondenrecht opgemerkt ${ }^{1}$ ): "neem b.v. aan, dat een vreemdeling, vertrouwd met onze taal, in Nederland een onderzoek naar den aard van het landbezit wil instellen, zal het dan voldoende zijn, wat de landbouwende klasse hem over huur, eigendom, vruchtgebruik, erfpacht, tienden, grondbelasting en wat niet al, mededeelt, of heeft zoo iemand niet behoefte aan de noodige kennis der wetten, waardoor deze toestanden beheerscht worden? Evenzoo is het ook met Java gelegen. Wat de weinig ontwikkelde inlander over den aard van het landbezit kan mededeelen, moet zich bepalen tot oppervlakkige waarneming; de kennis der Javaansche wetgeleerden bevat niet veel meer dan eene dorre casuïstiek, die in de praktijk goede diensten doet, doch volstrekt geene wetenschappelijke waarde bezit. Men moet dus zijne toevlucht nemen tot de Javaansche wetten, die men echter niet kan begrijpen, zonder met haren grondslag, het Mohammedaansche regt, goed bekend te wezen.»

Wat dit laatste betreft: het Mohammedaansche recht grondslag der Javaansche wetten, dat is teveel gezegd; men was in 1857 nog in den "zoeten bluf van het eerst Latijn»; Roorda's Javaansche wetten en S. Keijzer's Kitab Toehpah, door den bewerker in 1853 nog genoemd een Javaansch-Mohamedaansch Wetboek, golden als het begin en het einde der B. B. wijsheid. Intusschen, toen in 1867 de Controleurs B.B. A. J. Spaan en Mr. F. C. Valck onder den voor West-Java gecommitteerden Resident J. H. van der Palm in Bantam hun onderzoek naar de rechten van den Inlander op den grond instelden, wijdden zij, behalve aan die academische theorie, nauwgezet aandacht aan de historische traditie, de geschiedenis des sultanaats en aan de archiefstukken, niet in de minste plaats aan het hierboven aangehaalde rapport van Major Yule uit 1813. Merkwaardig werk, zorgvuldig overwogen, hebben deze onderzoekers voor Bantam geleverd: zij hebben echter, evenmin als Van Sevenhoven, zich een duidelijk beeld gevormd van des kleinen mans jasa met

1) De Britsche heerschappij over Java en Onderhoorigheden, blz. 223. 
betrekking tot 's Vorsten recht op den grond in zijn rijk, verkeerdelijk daarvoor eene verklaring zoekende in hetgeen aan de Delftsche Academie hun door Prof. S. Keijzer met betrekking tot het Mohammedaansch grondenrecht was gedoceerd ${ }^{1}$ ), en al te gemakkelijk naar den tijd van het Bantamsch sultanaat terugprojecteerend, hetgeen zij zestig jaar na de opheffing daarvan constateerden.

$\mathrm{Bij}$ hen stond voorop, dat de Bantamsche Vorst niet anders was dan "de administrateur van de inkomsten, die in de schatkist van de Muzelmansche gemeente vloeiden*, en verder, dat de ter beschikking dier gemeente staande grond, bij ontginning door Inlanders voor hun eigen rekening en risico, milik werd van den desaman; luidde immers in het Mohammedaansch recht de regel niet dat, alwie dooden grond levend maakt, eigenaar van dien grond is wanneer de ingebruikneming overeenkomstig het doel geheel is voltooid? Aldus geraakten zij tot de conclusie, dat alleen die gronden den Sultan als domein toebehoorden welke:

a. bij de invoering van den Islam bij verovering op de ongeloovigen verkregen waren, en

b. op last van den Sultan in heerendienst of op kosten van den Staat waren aangelegd;

met dien verstande verder, dat de door den kleinen man op eigen initiatief en voor eigen rekening ontgonnen sawahs, tipars en hoema's, krachtens het jasa-recht als diens milik zouden zijn te beschouwen.

Zóó vast was hun overtuiging, dat zij zelfs een onfeilbaar criterium voor het onderscheid tusschen die domeinlanderijen en milikgronden meenden te hebben gevonden, n.l. wanneer omtrent bouwgrond werd verklaard, dat oudtijds daarvan klelandjan» was verschuldigd, was die heffing - immers een pacht het bewijs dat het veld tot het sultanaatsdomein behoorde, terwijl wanneer de landman van zijn akker "pakoekoesoet" voldeed, die heffing als aanwijzing gold voor 's mans milik-recht.

$\mathrm{Nu}$ beduidt ngalandja in Bantam inderdaad nog steeds z.v.a. njéwa, d.i. huren, in pacht hebben, bijv. van droge gronden, en men mag ongetwijfeld in dien term «lelandjan» een herinnering zien aan de sultanaats-domeinpacht. Doch de term

2) Mr. H. D. Levyssohn Norman a. v. blz. 225 vlg. 
"pakoekoesoet» is minder duidelijk. Taalkundig beteekent pakoekoesoet eene heffing, welke niet aan een bepaalden regel is gebonden; adatrechtelijk, tegenwoordig evenals in $1867^{1}$ ), een kleine opbrengst in natura, welke de aanlegger van een tipar of hoema als recognitie voldoet, en die genoten wordt door het hoofd van de desa dan wel van de ampéjan, waartoe de ontgonnen rijstakker behoort. Als zoodanig is deze adat-recognitie op één lijn te stellen met de Lomboksche gondja en de Javaansche paměsi, eene oogstheffing of leverantie in natura ter zake van het in gebruik nemen van niet blijvend beplante gronden, welke recognitie in beginsel verschuldigd is aan den heer, den eigenaar des lands, maar die, omdat en zoo lang zij van weinig beteekenis is, door dezen ter beschikking van het landschaps- of dorpshoofd wordt gelaten. In de Javaansche Vorstenlanden was en is op de apanages ditzelfde het geval, en ontwaart men mede, dat het aandeel onbepaald is en varieert tusschen het $\frac{1}{3}$ of $\frac{1}{6}$ dan wel $\frac{1}{10}$ van den oogst. Spaan en Valk berichtten, dat de sawahs, waarvan pakoekoesoet werd opgebracht, veelal tot de minst vruchtbare dan wel het ongunstigst gelegen rijstvelden behoorden, en hieruit mag men m.i. concludeeren, dat dgl. sawahs over het geheel later tot stand gekomen zijn dan de overige, immers hoogst waarschijnlijk onder de werking van de hooger aangehaalde landrenteregeling van 1819 zijn bij-ontgonnen, in welk verband hun aanduiding als "milik»gronden volkomen begrijpelijk is. Doch uit den term "pakoekoesoet " af te leiden, dat de landman zijn akker reeds onder het sultanaat erfelijk individueel bezat, gaat te ver.

Jasa of oesaha beteekent werk, inspanning, en van ouds is erkend, ook onder de Javaansche vorstenbesturen, dat arbeid, dienst recht geeft op belooning; alleen bracht de practijk mede, dat dit loon gering was. Brengt nu de desaman een perceel tot het domein behoorende woesten grond in ontginning, dan bestaat zijn loon in het vol genot van den opbrengst tijdens een traditioneelen ontginningstermijn; is daarna de voltooide sawah bij het sultansdomein ingelijfd, dan geniet, bij de uitgifte van die sawah tegen padjeg of dienstplicht, de ontginner de voorkeur, zoo lang hij die verplichtingen nakomt, en zelfs gaat die voorkeur over op zijn erfgenamen. Al verder brengt het gebruik

!) Eindrésumé II tekst blz. 4 noot. 
mede, dat bij misdadig gedrag, niet voldoen aan zijne verplichtingen of verhuizing uit het dorp den desaman zijn bouwrecht wordt ontnomen, maar geschiedt zulks zonder gegronde reden, dan heeft hij aanspraak op een aandeel elders. Wanneer wij lezen ${ }^{1}$ ), dat de Sultan van Bantam wel eens jasa-velden had gekocht om die aan een ander te geven, dan zal dit wel niet anders geweest dan een vergoeding van aan de ontginning werkelijk besteede uitgaven, welke nog niet voldoende waren opgewogen door het genot van padi-oogsten, bijv. binnen den traditioneelen driejarigen ontginningstermijn voor sawahs.

Met betrekking tot de in Yule's rapport geschetste Bantamsche poesaka-landerijen meenden Spaan en Valck te moeten komen tot de conclusie, dat zoowel de verkoopbare als de niet-verkoopbare poesaka's niet anders waren dan apanages (petjaton of poesaka ladèn), en als zoodanig in wezen gelijk aan de Mohammedaansch-rechtelijke concessiën van inkomsten, terwijl verkoop van dgl. sawahs h.i. was te beschouwen als een ingeslopen misbruik, behalve ingeval de Sultan die sawahs met eigen middelen had laten ontginnen, en die velden mitsdien zouden zijn te beschouwen als diens jasa banda, zooals het geval was met de sawah negara.

Wanneer men nu echter op Lombok ziet, dat bij een op verovering des rijks gegrond Vorstenbestuur naast een zeer uitgestrekt, tegen dienstplicht uitgegeven domein staat een particulier bezit van met vergunning van den Vorst vervreemdbare gronden, oorspronkelijk door hem volledig geschonken; een bezit dat in het algemeen eigen is aan 's Vorsten familie, zijn rijksgrooten en aanzienlijken, doch door geoorloofden verkoop zelfs aan kleine lieden in handen valt, dan begint men allicht met Major Yule het er voor te houden, waar deze toch zooveel dichter bij het Sultanaatsbestuur stond dan de onderzoekers van 1867, dat in Bantam het grondenrecht niet berustte op zuiver Mohammedaansch-rechtelijken grondslag maar op oud-Javaansche begrippen, die m.m. zijn blijven voortleven eenerzijds op Bali en Lombok en anderzijds in Demak en Banten. Het feit, dat in Bantam de verkoopbare sawahs niet aan schatting, noch in geld, noch in natura jegens den Sultan waren onderworpen, en de eigenaren alléén gehouden waren hem met hun onder-

1) Van Sevenhoven bij Spaan en Valok, t. a. p. bIz. 11/12. 
hoorigen bij te staan het zij om krijg te voeren of openbare wegen te maken, - ook deze uiteenzetting komt zóó merkwaardig overeen met het karakter van het Lomboksche drwé-djaba-bezit, dat het m.i. aangewezen is om in beginsel staat te maken op Yule's bevindingen. Apanages in grond, zooals in Bantam de aanzienlijksten in den Lande, met name de Rijksbestuurder en de Opperpriester hebben gehad, kwamen op Lombok alléén voor met betrekking tot dorps- en waterschapshoofden als ook tot de breede schare van kraton-dienaren en dienstplichtigen van zekeren rang (loepoet bedil, perwangsa enz.), in den trant van die, welke in Bantam een aandeel ontvingen in de sawahnegara; voornaam apanage-bezit is echter volledig bekend uit de Javaansche Vorstenlanden, waar tevens blijkt dat deze vorm van grondenrecht nog al verschilt van de Mohammedaanschrechtelijke iqta. Tusschen oud-Bantam en de tegenwoordige Vorstenlanden bestaat grondenrechtelijk merkwaardigerwijze dit verschil, dat in Midden-Java het Inl. eigendomsrecht der sawah akoe niet meer voorkomt, en het is daarom, dat wij m.i. mogen aannemen dat dit instituut uit de Javaansche landsinstellingen is verdwenen na den overgang der opperheerschappij over Java op Mataram.

Inlandsch eigendom uit den tijd van het Bantamsch sultanaat is indertijd geacht het recht dat omstreeks 1870 het Lampongsche hoofd Batin Sangoen Ratoe, Bandar van Pedada, vindiceerde op het eiland Groot-Lagoendi c.a. en Pangeran Singa Brangta van de marga Radjabassa op de eilanden Krakatau, Seboekoe en Sebesi in straat Soenda ${ }^{1}$ ). ( $\mathrm{Hij}$ is, leest men met betrekking tot eerstgenoemd hoofd, wel niet hij magte om van zijn eigen-

1) Résumé-regten op Sumatra op de onbeb. gronden uitgeoefend, 1872 blz. 102, 107 en 94/96. Dergelijke eigendomspretenties droegen destijds, d. i. vóór de zoo vaak aangevochten Domeinverklaring, welke de Regeering in een wel is waar niet onaanvechtbare, maar toch sterke rechtspositie plaatste, niet louter een academisch karakter. In de Lampongs was het de Bandar van Pedada, die uit kracht van een zoodanigen eigendom de Lagoendi-eilanden voor 20 jaar verhuurde aan A. A. Chaulan; in Menado wilde het districtsbestuur het eiland Bangka verkoopen aan Van der Parra Breton Vincent, een quaestie, waarover de Indische Regeering geprocedeerd heeft tot voor den Hoogen Raad. De uitspraak is geweest ten gunste der Regeering (1878). Met betrekking tot zoodanigen landverkoop in de Minahasa teekende Dr. G. A. Wilken aan, dat, volgens de adat, verkoop van gronden aan vreemdelingen niet gesschieden mag. 
domsregt op deze eilandengroep eenig authentiek bewijs te produceeren; echter is dat regt aan hem en zijn geslagt niet alleen nooit betwist geworden, maar hebben de hoofden en opgezetenen van zijne marga, ook die der overige deelen dezer residentie, hem steeds als eigenaar erkend." Tegenover deze vermeende Sultansschenking opkomende voor de marga-bevolking, schreef de Controleur B. B. Stakman daarbij: «dat de Bandars in die streken zich als eigenaars van den geheelen margagrond willen doen gelden, zegt niets, daar de bevolking dit eigendomsregt niet erkent, en zij vroeger alleen door dwang in die erkenning tijdelijk heeft moeten berusten. Usurpatie geeft trouwens geen regt, zoodat daar niet op behoeft gelet te worden.»

Wij zijn thans in staat ons een duidelijker voorstelling te vormen van den vermoedelijken staat van zaken met betrekking tot de Lampongsche grondrechten door de gelukkige ontdekking van een Bantamsch-Javaanschen piagem betreffende de in de baai van Telokbetong gelegen Tjoendoeng-eilandjes. Deze piagem, gedagteekend H. 1166 (A. D. 1752), bevat de bekrachtiging door den Sultan van Bantam van een in de hoofdstad des rijks in hoogste instantie genomen beslissing in zake een tusschen Arja Tanoedjaja, poenggawa van Telok (bětong) en een aldaar mede woonachtigen poenggawa Pangeran Koesoemawangsa gerezen geschil over het gebruik van de klapperboomen enz, op de tot Telok behoorende onbewoonde Tjoendoeng-eilandjes, een geschil dat een gevecht ten gevolge had gehad, waarin aan weerszijden dooden en gewonden waren gevallen.

Tijdens het Bantamsch sultanaat werd in de Lampongs het vorstelijk gezag vertegenwoordigd door een viertal voorname Bantamsche hoofden, de djěnangs van Semangka, Telokbetong, Kalianda en Toelangbawang, wier hoofdtaak bestond in het toezicht op de peper-aangelegenheden en in het bijleggen der tusschen de poenggawa's (de eigenlijke volkshoofden over de désa's of marga`s) gerezen geschillen, en, zoolang de Sultan van Bantam in de Lampongs den steun had van de te Toelangbawang en te Semangka gevestigde Compagniesmacht, zóó lang was diens macht geenszins denkbeeldig.

Het lagere volks- en landsbestuur berustte bij de poenggawa's der hoofdnederzettingen, - een erfelijk gezag, behoudens aanwijzing van den persoon door het eigen volk. $Z_{i j}$ werden aangemerkt als hoofden over tot's Vorsten land behoorende desa- 
gebieden (wěwěngkon désa ${ }^{1}$ ); waar evenwel die erfelijkheid streng erkend en in verband werd gebracht met een zeker gebied, lag later de pretentie voor de hand dat deze Lampongsche poenggawa's "hun» land konden verkoopen. Een helaas niet meer te dateeren Toelangbawangsche piagem, afgegeven door den Bantamschen Rijksbestierder, bevestigt bijv. een drietal zonen van Pangeran Setjadita, den poenggawa over Toelangbawang, te zamen en erfelijk in het genot van een nauwkeurig begrensd leenroerig gebied, en het is deze piagem ${ }^{2}$ ) die, gepaard aan een mededeeling van den Assistent-Resident Kruseman uit 1817, ons verduidelijkt

1) T. B. G. dl. 35 (1893) blz. 119 vgl. Met betrekking tot de daarin voorkomende twijfelachtige woorden deelde $R$. Gondosapoetro mij mede dat in het Bantamsch-Jav. pantjas (de tekst heeft dj) beteekent zich met de wapens verzetten, terwijl "kadjebel" is te lezen katjambil $=$ krambil $=$ klapa. Dit proces werd oorspronkelijk te Bantam berecht door den Mangkoeboemi, den Pěkih en den Opperdjaksa omdat het ging zoowel om het bezit der Tjoendoeng-eilandjes, dus een quaestie over land (boemi) als om de boete wegens het dooden van volk, een aangelegenheid voor de hoekoem, en ten slotte het wegnemen van karbouwen, hetwelk onder de pradata van den Opperdjaksa viel. Brandes noemde den Pěkih Opperdjaksa, vermoedelijk op grond van Van Ossenberch's mededeeling in 1761, B. K. I. 4, V. (1881) blz. 114 :..." den Opperste Priester en Regter, soo in geestelijke als weerelse saaken, genaamt Ké Focke Nadjam oedin," waarbij speciaal gedoeld wordt op de „crimineele procedures". Blijkbaar had Bantam eenzelfde rechtspleging als Mataram (door beide sultanaten ontleend aan Demak?), met dezelfde drie rechtbanken en overeenkomstige fora: de Soerambi van den Pĕkih, de Balemangoe van den Adipati of Mangkoe Boemi en de Pradata onder den Among Pradja, den oppersten Djaksa. Laatstgenoemde heette in het zich naar Java's model georganiseerd hebbend Palembang eertijds Nata Pradja, had daar eveneens zijn eigen recht. bank in, zou men kortweg zeggen, eiviele zaken, terwijl de Nata-Agama als godsdienstig rechter en de Rijksbestuurder als Nata-Radja hun eigen jurisdictie hadden. Waar V. Ossenberch t. a. p. spreekt van een Radeen Aria... Tweede in 's Konings Geheimen Raad en Regeering onder den naam van Radeen Jacattaxa, vermoed ik dat dit laatste woord een verschrijving is voor Djaksa. - Over de plaats, welke in de Bantamsche rechtspraak de heilige wet bekleedde, licht V. O. ons aardig in, waar hij den ouden Pěkih laat vonnis vellen "over misdadigers, waartoe hij den Alcoran of het Mahometaanse wetboek voor den dag brengt en wat exempel op deese en geene voorvallen applicabel syn aantoont, mits niet strijdende is met het preveligie, dat aen sommige negorijen zeedert lange jaaren vergunt is, van geen bloet te vergieten, 't geen dan altoos doorgaat."

2) T. B.G. dl. 29, Lampongsche piagem $\mathrm{n}^{\circ}$. IV. Vgl. ook hetgeen Du Bois mededeelde over het splitsen van tioe's en de pěnětes bongkar in T. N. I. 1852 I blz. 249. Onze piagem noemt het gebied van den poenggawa "wěwěngkon desa", en dit aequivaleert m. i. aan het gebied van een marga (Lamp. mégo) of bangsä [t. a. p. 327]. 
waarom in 1752 in Telokbetong een tweetal poenggawa's elkaar gingen beoorlogen; "wanneer de pungauwa van eene kampong, schreef Kruseman, verscheide zoons heeft, geeft hij aan ieder derzelven het bestuur over eenige huizen om hun daardoor na zijn overlijden voor geheele af hankelijkheid van hun oudsten broeder te behoeden; na de dood des vaders blijft dit getal huizen hun eigendom en het is geen der bewoners daarvan, nog hunne nakommelingen, geoorloofd zich buiten gebied dezer Pungauwas te begeven zonder derzelver toestemming. Ieder dezer kleine hoofden hebben het regt (sic! in 1817) hun gebied af te staan of te verkoopen na goedvinden., ${ }^{1}$ )

Raadplegen wij nu de in 1752 met betrekking tot de twistende poenggawa's van Telokbetong genomen beslissing, dan zien wij, dat Arja Tanoedjaja in dit padoe-proces ${ }^{2}$ ) erkend werd als de winnende partij op grond van bij hem berustende, vroegere piagems (m.a.w. hij was het eigenlijk hoofd over Telok); voorts, dat de verliezende partij Pangeran Koesoemawangsa wel is waar mocht blijven wonen in het gebied van Arja Tanoedjaja, maar dat aan laatstgenoemde zou verblijven de haven en het bestuur (bandar lan paparèntahan), terwijl ten opzichte der Tjoendoengeilandjes werd bepaald, dat deze, na te zijn overgebracht in de handen des Sultans, werden in leen gegeven aan Arja Tanoedjaja [ing asta Dalem, ginadoehakěn ing A. T.], en dat mitsdien, als poenggawa's of kleine lieden, die een feest (hadjat) aanlegden dan wel naar Bantam wilden (overvaren), klappers of andere zaken op die eilandjes kwamen halen, Arja Tanoedjaja hen niet mocht bemoeilijken, tenzij dezen zulks zouden doen om die vruchten te verkoopen ${ }^{3}$ ).

1) H.S. $\mathrm{n}^{\circ} .407$ in de bibliotheek van het Kon. Instituut voor Taal-, Landen Volkenk. v. N. I., te 's-Hage.

2) Padoe, wijl een rechtsquaestie (mas'alah) tusschen partijen over het genot van een zeker gebied, (arěboet kajoc, lan arěboet lěladèn lan arěboet bandar lan arěboet poeloe tjoeṇḍoeng) zonder dat de Vorst zelf daarbij partij was.

3) Vgl. Du Bois' mededeeling T. N. I. 1857 I over het recht der Lamp. margahoofden (zgn. radja's over een tioe) bij ladang-aanleg op de "saksi (lees: séwa) boemi", bestaande in een klapper en eenige koelak's rijst, voorts op de papadangan enz., recognitiën, verschuldigd door anderen dan de margaof tioegenooten. Aangezien in Telok de margahoofden onderling aan het twisten waren gegaan, besloot de Sultan als Opperheer de eilandjes rechtstreeks onder zich te brengen, in denzelfden geest als ook de Vorst van Lombok bij onoplosbare quaesties tusschen partijen het betwiste voorwerp 
Niet eigendom was het dus, wat zulk een Lampongsche poenggawa aan recht op den grond in zijn gebied had maar het genot en het leenroerig bezit daarvan, en men leert uit dezen piagem tevens, dat bij hoogloopende geschillen de Vorst zich voorbehield om, naar bevind van zaken, ter verzoening der strijdige belangen als opperbeer-domeinbezitter eene bijzondere regeling te treffen. Een begrip, dat geenszins tot Bantam beperkt was, maar men bijv. ook terugvindt in het oude Palembang, dat eveneens het Javaansche domeinrecht huldigde: zóó bijv. waar deze Sultan den lieden van zekere dorpen toestond om gaga's of talang's aan te leggen op de alas-gronden van een andere desa ${ }^{1}$ ); en in gelijken trant lezen wij in de Lomboksche Peswara ${ }^{2}$ ) - ook hier ter voorkoming van herhaalde vechtpartijen - - dat alle grond die niet door den Vorst gereserveerd is, voor ieder beschikbaar moet zijn als weidegrond, zonder daarbij rekening te houden met desagrenzen.» De Lampongsche bandars spraken van "saja poenja tanah", en zij konden dit in zekeren zin doen als erfelijke poenggawa's, tevens marga-volkshoofden, maar het is eene vergissing van sommige ambtenaren geweest, om in dit recht op het genot van den grond als poenggawa te zien een eigendomsrecht, het was niet meer dan gadoehan, in den trant als het geval is geweest met betrekking tot de Sasaksche hoofden van desa's in Midden Lombok.

De toenmalige Resident der Lampongsche Districten Pruijs van der Hoeven heeft, blijkens zijne in voetnooten bij het Lampongsch Résumé vervatte aanteekeningen, die vergissing gevoeld, gelijk hij ook uitdrukkelijk vastlegde, dat de bevolking zelf op haar gronden niet meer dan een gebruiksrecht vindiceerde, en, in dit licht bezien, verdwijnt vrij wel de in dat Résumé nog al eens doorschemerende voorstelling van een wettig marga-recht tegenover een geüsurpeerd sultansrecht. Zoo iets is trouwens kwalijk vereenigbaar met de Javaansche adat, bij deze dient ook het recht van het standpunt van den Vorst uit te worden bezien, en dan ontwaart

onder zich bracht, naast te, hetgeen genoemd werd gadjah-katjapa, naar een parabel in de Adiparwa. Dat Arja Tanoedjaja de personen, die op de eilandjes kwamen om klappers te plukken ten verkoop, mocht weren, ligt in den aard van zijn recht op het genot van de voortbrengselen van zijn gebied.

1) T. B. G. dl. 45 (1902) blz. 274, alinea's 13 en 14.

2) F. A. Liefrinck, de landsverordeningen der Balische Vorsten van Lombok II blz. 149 , 
men verder dat elk persoon, die op eenige wijze genot van 's Vorsten grond heeft, binnen zekere grenzen vrij is om daaruit alle baat te trekken, zonder dat de Vorst zich steeds met de uitoefening van dat recht inlaat. Maar tevens leert men, dat, indien er twist ontstaat, recht wordt gesproken naar 's Vorsten domeinbegrip; en dat indien de landsvrede bedreigd wordt, de Vorst diep ingrijpt, terwijl hij, die, 's Vorsten rechtspraak niet achtend, zich verzet, zoo noodig, wordt gedood.

Een dergelijke absolute heerschappij, een dusdanig domeinrecht, gepaard gaande aan een zoo goed als algeheele macht over lijf en goed der onderdanen, wordt, naar de Javaansche Vorstenlanden en Bali zoowel als Lombok leeren, door de bevolking gewillig aanvaard, zoolang behoorlijke orde, matige veiligheid en redelijke tegemoetkoming aan levensbelangen haar verzekerd blijft. In zulk een ouderwetsch geregeerd rijk is botsing tusschen volks- en vorstenrecht een ongehoorde zaak, maar wanneer den Vorst de macht ontzinkt, gaat de belangenstrijd groote afmeting aannemen, ontwaken pretenties, en ontstaat langzamerhand een chaos. Dit rond in de Lampongs plaats, toen het Hollandsch gezag zich daaruit terugtrok: de Sultan van Bantam was niet meer bij machte zich te doen gelden; zeeroovers teisterden de stranden; en toen bij het herstel van ons gezag, het Bestuur de zoo hoog noodige voorlichting miste omtrent het vroeger gegolden hebbende landrecht, hadden drieste hoofden zich rechten aangematigd, welke hun nimmer hadden toebehoord, en heetten valsche piagems die rechten te staven, tot den eigendom toe van elke aardkluit, van elken waterdrop in de rivier van het voormalig gezagsgebied. ${ }^{1}$ ) En wanneer dan na een eenigszins ruim tijdsverloop het Europeesch gezag plaatselijk tracht uit te vinden wat oudtijds onder het inheemsch Vorstenbestuur recht en wet is geweest, dan hoort dit bij herhaling belanghebbenden een beweerd recht voordragen en staat het vaak in het onzekere wat oudtijds als recht gold. Te eer nog, omdat inmiddels onder ons gezag ingrijpende veranderingen in het landsbestuur en in de volksinstellingen zijn gekomen, sommige bewust, andere onbewust. Ligt het alsdan

1) Vgl. die van het hoofd van Bakoeng in T. N. I. $1856 \mathrm{II} \mathrm{blz.} \mathrm{353/4} \mathrm{als} \mathrm{ook}$ die van Raden Intan bij Dr. Hoesein Djajadiningrat, Critische Beschouwing van de Sadj. Banten blz. 119 vlg. 
in den aard der zaak om als adat, als bestaand volksrecht aan te merken alléén datgene uit den ouden tijd hetwelk blijkt zich te hebben gehandhaafd, verkeerd zou het naar mijne meening zijn om te verzuimen daarbij tevens na te gaan in welke oude landsinstellingen die nieuwe adat geworteld is geweest, omdat alleen daardoor dit "volksrecht» juist is te beoordeelen en op zijn rechte waarde valt te schatten.

Met het komen van een land, dat onder inheemsch vorstenbestuur stond, onder rechtstreeksch Hollandsch gezag, breekt voor dat land en volk een merkwaardige periode van aanpassing aan, in de eerste plaats met betrekking tot het grondenrecht. Automatisch worden alle wetten en algemeene NederlandschIndische rechtsbegrippen plotseling gangbaar, en indien overigens de locale wetgever zwijgt, inmiddels handelt het Bestuur, terwijl de fiscus geheel anđers werkt dan voorheen. Ook al wordt het beginsel gehandhaafd, dat de grond domein van den Staat is, aanstonds wordt de domeinpacht verlaagd, en het padjegvrij bezit op gelijken voet als de andere grond belast; de bijzondere vorstendiensten vallen weg, de apanages houden, behalve voor het dorpsbestuur, op; en in het nieuwe systeem heeft de Staat er geen belang bij om den landman het recht te onthouden om zijn veld te verkoopen, tenzij aan niet-Inlanders. Die groote verandering voltrekt zich niet ineens. Wat tenminste het Bantamsche grondenrecht aangaat, is die verandering geleidelijk geweest. Bijna drie kwart eeuw heeft Bantam er over gedaan om het in de sawah negara overgebleven laatste spoor van het sultanaats-apanage-bezit uit te wisschen; minstens vijftig jaar heeft het geduurd, eer het jasabegrip van den sultanstijd zich heeft ontwikkeld tot het erfelijk individueel bezit van den grond, en tengevolge daarvan is het oude domeinbegrip met betrekking tot de inlandsche bouwvelden, tot onherkenbaar wordens toe verbleekt zoodat wel eens aan de realiteit van het vorstelijk domeinrecht is getwijfeld.

Wij hebben thans gezien, wat de geschiedenis ons daarvan leert met betrekking tot Bantam: hoe die ontwikkeling zich heeft toegedragen in Cheribon, de Preanger en Buitenzorg worde een andermaal aan de orde gesteld. 